\title{
Different revegetation types alter soil physical-chemical characteristics and fungal community in the Baishilazi Nature Reserve
}

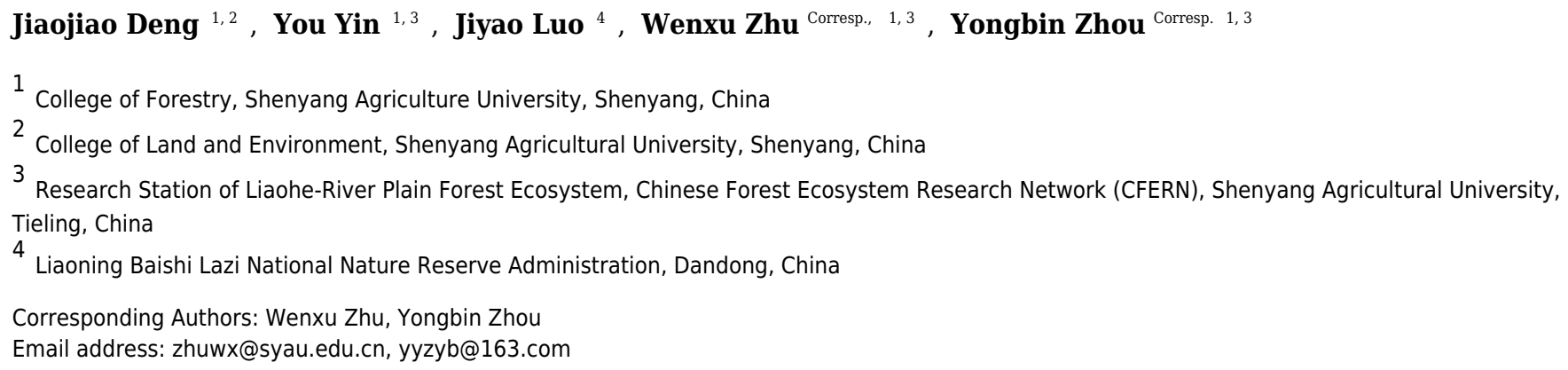

The effects of different revegetation types on soil physical-chemical characteristics and fungal community diversity and composition of soils sampled from five different revegetation types (JM, Juglans mandshurica; QM, Quercus mongolica; CB, coniferbroadleaf forest; LG, Larix gmelinii; PK, Pinus koraiensis) in the Baishilazi Nature Reserve were determined. Soil fungal communities were assessed employing ITS rRNA Illunima Miseq high-throughput sequencing. Responses of the soil fungi community to soil environmental factors were assessed through canonical correspondence analysis (CCA) and Pearson correlation analysis. The coniferous forests (LG, PK) and conifer-broadleaf forest (CB) had reduced soil total Carbon (C), total Nitrogen (N), and available $N$ values compared with the broadleaf forest (JM, QM). The average fungus diversity according to the Shannon, ACE, Chaol and Simpson index were increased in the JM site. Basidiomycota, Ascomycota, Zygomycota, and Rozellomycota were the dominant fungal taxa in this region. The phylum Basidiomycota was dominant in the $\mathrm{QM}, \mathrm{CB}, \mathrm{LG}$, and PK sites, while, Ascomycota was the dominant phylum in the JM site. The clear differentiation of fungal communities and the clustering in the heatmap and in NMDS plot showed that broadleaf forests, conifer-broadleaf forest, and coniferous forests harboured different fungal communities. The results of the canonical correspondence analysis (CCA) showed that soil environmental factors, such as soil $\mathrm{pH}$, total $\mathrm{C}$, total $\mathrm{N}$, available $\mathrm{N}$, and available Phosphorus $(\mathrm{P})$ greatly influenced the fungal community structure. Based on our results, the different responses of the soil fungal communities to the different revegetation types largely dependent on different forest types and soil physicochemical characteristic in Baishilazi Nature Reserve. 
1 Different revegetation types alter soil physical-chemical characteristics and fungal community in

2 the Baishilazi Nature Reserve

3 Jiaojiao Deng ${ }^{1,2}$, You Yin ${ }^{1,3}$, Jiyao Luo $^{4}$, Wenxu Zhu ${ }^{1,3 *}$, Yongbin Zhou ${ }^{1,3^{*}}$

$4 \quad{ }^{1}$ College of Forestry, Shenyang Agriculture University, Shenyang, China

$5 \quad{ }^{2}$ College of Land and Environment, Shenyang Agriculture University, Shenyang, China

$6 \quad{ }^{3}$ Research Station of Liaohe-River Plain Forest Ecosystem, Chinese Forest Ecosystem Research

7 Network (CFERN), Shenyang Agricultural University, Tieling, China

$8{ }^{4}$ Liaoning Baishi Lazi National Nature Reserve Administration, Dandong, China

*Corresponding Author

Wenxu Zhu, Yongbin Zhou

No. 120, Dongling Road, Shenhe Distinct, Shenyang, Liaoning Provience, 110161, China Email address: zhuwenxu.315@163.com,yyzyb@163.com

\section{Abstract}


28

29

30

The effects of different revegetation types on soil physical-chemical characteristics and fungal community diversity and composition of soils sampled from five different revegetation types (JM, Juglans mandshurica; QM, Quercus mongolica; CB, conifer-broadleaf forest; LG, Larix gmelinii; PK, Pinus koraiensis) in the Baishilazi Nature Reserve were determined. Soil fungal communities were assessed employing ITS rRNA Illunima Miseq high-throughput sequencing. Responses of the soil fungi community to soil environmental factors were assessed through canonical correspondence analysis (CCA) and Pearson correlation analysis. The coniferous forests (LG, PK) and conifer-broadleaf forest $(\mathrm{CB})$ had reduced soil total Carbon $(\mathrm{C})$, total Nitrogen $(\mathrm{N})$, and available $\mathrm{N}$ values compared with the broadleaf forest (JM, QM). The average fungus diversity according to the Shannon, ACE, Chaol and Simpson index were increased in the JM site. Basidiomycota, Ascomycota, Zygomycota, and Rozellomycota were the dominant fungal taxa in this region. The phylum Basidiomycota was dominant in the QM, CB, LG, and PK sites, while, Ascomycota was the dominant phylum in the JM site. The clear differentiation of fungal communities and the clustering in the heatmap and in NMDS plot showed that broadleaf forests, conifer-broadleaf forest, and coniferous forests harboured different fungal communities. The results of the canonical correspondence analysis (CCA) showed that soil environmental factors, such as soil $\mathrm{pH}$, total $\mathrm{C}$, total $\mathrm{N}$, available $\mathrm{N}$, and available Phosphorus (P) greatly influenced the fungal community structure. Based on our results, the different responses of the soil fungal communities to the different revegetation types largely dependent on different forest types and soil physicochemical characteristic in Baishilazi Nature Reserve.

Introduction

Due to long-term human disturbances and intensive land use, the native vegetation of temperate 
55

56

57

zones in China is severely damaged, with reduced biodiversity and deteriorated ecological functions (Liu \& Diamond, 2005). Numerous researches have established that vegetation restoration is an important measure to obtain ecological benefits (Gao et al., 2002; Nunezmir et al., 2015; Xiao et al., 2015), such as enhancing biodiversity (Dosskey et al., 2012), the restoration of damaged natural ecological system (Fule' et al. 2012), and the recovery of ecosystem services (Benayas \& Bullock, 2009). Revegetation also has numerous positive effects on soil physicochemical characteristics, such as soil bulk density, field capacity (Zhang et al., 2018), infiltration rates (Wu et al., 2016), soil organic carbon (Georgiadis et al., 2017), and soil nitrogen (Fu et al., 2010). Feedback processes of plant-soil play crucial roles in altering the structure and dynamics of soil microorganisms (Herrera Paredes et al., 2016). The soil microbial community, which is a key bridge that connects the plant community with soil processes, is one of the most important regulators of soil nutrient transformation (Cheng et al., 2013). Soil microorganisms can not only directly affect the storage of soil nutrients via microbial biomass, but also can indirectly effect soil nutrient transformation through the metabolic activity (Jangid et al., 2013; You et al., 2014). In this sense, different revegetation types, combined with accurate biological monitoring, can achieve effective and targeted restoration goals (Collen \& Nicholson, 2014). However, studies on the changes in soil microbial community dynamics, despite the important role of microorganisms in biogeochemical cycling, are still scarce (Guo et al., 2018).

Fungal community and diversity have important influences on plant communities and ecosystems (van der Heijden et al., 2008; Devi et al., 2012). Furthermore, fungi play crucial roles in many respects of ecosystem development (Chen et al., 2010; Geml et al., 2014), determining biochemical cycles in continental ecosystems (Tedersoo et al., 2014). Fungal diversity and community composition are closely related to numerous abiotic and biotic factors, such as elevation (Kernaghan \& Harper, 2010; Bahram et al., 2012), soil environment (Peter et al., 2001; Dickie et al., 2002), plant species (Lovett et al., 2004; Weand et al., 2010), plant diversity (Dickie, 2007; Waldrop et al., 2006), and stand age (Zhu et al., 2010; Wallander et al., 2010). An increasing number of studies have shown that a number of soil properties, including soil $\mathrm{pH}$ (Fierer \& 
82

83

84

Jackson, 2006), soil texture (Girvan et al., 2003), and soil nitrogen availability (Frey et al., 2004), can be associated with changes in fungal community structure; these soil characteristics are often influenced by vegetation cover at the same area. Any changes in the fungal community in the process of ecological restoration are key indicators of restoration success (Harris, 2009). A previous study has reported that replanting native vegetation can result in dramatic shifts in the fungal community towards that of the natural fungal community (Yan et al., 2018). Unfortunately, few researchers have addressed the connection between the different revegetation types and the fungal community structure in broadleaf forests, coniferous forests, and conifer-broadleaf forest. Specifically, it is unclear which soil environmental factors play the principal roles in driving fungal dynamics. Previous work has concentrated on the relationships between soil characteristics and soil fungi under grassland and leguminous species (Harrison \& Bardgett, 2010), but there remains a need for interpreting which of these factors were the dominant influence on the soil fungal communities in different revegetation types.

As the national nature reserves, the Baishilazi Nature Reserve is located in the mountainous region of the eastern Liaoning Province, China. The reserve was established in 1988 and is part of the Changbai Mountain system. The original vegetation was broadleaf Pinus koraiensis forests, which were severely damaged due to the over-exploitation of the past 100 years. At present, the vegetation mainly consists of natural secondary forests and coniferous forests, which provides a unique opportunity to investigate the soil fungal communities of different revegetation ecosystems under the same climatic conditions. Numerous researches have investigated the changes in soil microbial biomass (Fan et al., 2014), and soil organic carbon contents (Qi et al., 2017) in different revegetation types; however, studies on the impacts of different reforestation pathways on the soil fungal community are scarce. In this context, we applied pyrosequencing of the ITS rRNA gene to explore both the diversity and composition of soil fungal communities in responses to different revegetation types from five sites in the Baishilazi Nature Reserve, Liaoning Province, China. Our objective was to examine how soil fungi may respond to different revegetation types and, more specifically, how the abundance and composition of soil fungal communities respond to changes 
109 in soil physicochemical properties.

110 Material and methods

\section{Site description}

112 The field study was carried out at the Baishilazi Nature Reserve (approval number\# 20170628-7),

113 the eastern mountainous areas of Liaoning Province $\left(40.83^{\circ} \sim 40.95^{\circ} \mathrm{N}, 124.74^{\circ} \sim 124.96^{\circ} \mathrm{E}\right.$;

114 Fig. 1). It is a comprehensive nature reserve with forest ecosystem as the main protection object.

115 The reserve covers an area of 7407 ha and belongs to the Changbai mountain range. This area is 116 characterized by a continental monsoon climate, with long cold winters, warm wet summers, and 117 a higher diurnal temperature variation. The annual mean amount of evaporation is $885 \mathrm{~mm}$, with 118 an annual average temperature of $6.4{ }^{\circ} \mathrm{C}$, and an average annual precipitation of $1158 \mathrm{~mm}$. The 119 soil type is Brown soil (Zhang et al., 2017). The region has a relatively rich and unique 120 biodiversity, possessing significant ecological status and scientific value both in China and on a 121 global level. The characteristics of the five selected study samples are listed in Table 1.

\section{Soil sampling}

123 In July 2017, we sampled soils from three randomly selected $20 \mathrm{~m} \times 20 \mathrm{~m}$ plots per forest type 124 after removal of the litter layer. The sampled forest types were including Juglans mandshurica 125 (JM), Quercus mongolica (QM), conifer-broadleaf forest (CB), Larix gmelinii (LG), and Pinus 126 koraiensis (PK), giving a total of 15 plots. Soil samples were collected use of a soil auger with 8 $127 \mathrm{~cm}$ in diameter, and $10 \mathrm{~cm}$ deep. The soils of 15-20 points were collected at a depth of $0-10 \mathrm{~cm}$ along an "S" shaped path to ensure the representativeness of soil samples in each forest, mixed together and placed in sterilized ziplock bags as a replicate sample. Identically, in each revegetation form, three subsamples were collected. Immediately arrival to the laboratory the samples were stored cooled boxes, sieved ( $2 \mathrm{~mm}$ mesh) to undock roots and dopant, and divided into two sub-samples, of which one was air-dried and used for physical and chemical analyses, and the other one was stored at $-80{ }^{\circ} \mathrm{C}$ prior to DNA extraction and used for microbial analyses. 
135

136

137

138

139

140

141

142

143

144

145

146

147

148

149

150

151

152

153

154

155

156

157

158

159

160

161

Soil $\mathrm{pH}$ was measured using a $\mathrm{pH}$ meter after shaking a soil-water (1:5w/v) suspension for $30 \mathrm{~min}$ (Bao, 2000; Ren et al., 2017). Soil total C and total N were measured with an Elemental Analyzer (Elementar, Germany) (Schrumpf et al., 2011). Available nitrogen (AN) was determined by the alkali diffusion method (Bao, 2000). Total phosphorus (TP) was measured by spectrophotometry after wet digestion with $\mathrm{HClO}_{4}-\mathrm{H}_{2} \mathrm{SO}_{4}$ (Parkinson and Allen, 2009). Available phosphorus (AP) was measured using the colorimetric method with extraction via $0.5 \mathrm{M} \mathrm{NaHCO}_{3}$ (Emteryd, 1989).

\section{DNA extraction and PCR amplification sequencing}

Total fungal genomic DNA samples were extracted from $0.5 \mathrm{~g}$ of soil using the Fast DNA SPIN extraction kits (MP Biomedicals, Santa Ana, CA, USA), according to the manufacturer's instructions. The quantity and quality of extracted DNAs were measured using a NanoDrop ND1000 spectrophotometer (Thermo Fisher Scientific, Waltham, MA, USA). The primer sets: ITS1F (5'-CTTGGTCATtTAGAGGAAGTAA-3') (Gardes \& Bruns, 1993) and ITS2F (5'GCTGCGTTCTTCATCGATGC-3') (White et al., 1990) were selected to target the fungal ITS1 region. Sample-specific 7-bp barcodes were incorporated into the primers for multiplex sequencing. The PCR amplification required two steps. During the first step, each of three independent $25 \mu \mathrm{l}$ reactions per DNA sample included $5 \mu \mathrm{l}$ of Q5 reaction buffer $(5 \times), 5 \mu \mathrm{l}$ of Q5 High-Fidelity GC buffer $(5 \times), 1 \mu \mathrm{l}(10 \mathrm{uM})$ of each forward and reverse primer, $2 \mu \mathrm{l}(2.5 \mathrm{mM})$ of dNTPs, $0.25 \mu$ l of Q5 High-Fidelity DNA Polymerase (5 U/ $\mu \mathrm{l}), 2 \mu \mathrm{l}$ of DNA Template, and 8.75 $\mu \mathrm{l}$ of $\mathrm{ddH}_{2} \mathrm{O}$. Cycling conditions were $98^{\circ} \mathrm{C}$ for $5 \mathrm{~min} ; 25$ cycles of $98{ }^{\circ} \mathrm{C}$ for $15 \mathrm{~s}, 55^{\circ} \mathrm{C}$ for 30 $\mathrm{s}, 72{ }^{\circ} \mathrm{C}$ for $30 \mathrm{~s}$, followed by $72{ }^{\circ} \mathrm{C}$ for $5 \mathrm{~min}$. The PCR amplicons were purified with Agencourt AMPure Beads (Beckman Coulter, Indianapolis, IN) and quantified using the PicoGreen dsDNA Assay Kit (Invitrogen, Carlsbad, CA, USA). After the individual quantification step, amplicons were pooled at equal amounts, and pair-end $2 \times 300$ bp sequencing was performed using the Illlumina MiSeq platform with the MiSeq Reagent Kit v3.

\section{Sequence data analysis}

The raw data yielded from Illumina sequencing were analyzed using QIIME software (v1.9.0) and the UPARSE pipeline (Zhong et al., 2015). The UPARSE pipeline was performed for taxonomic 
162

163

164

165

166

167

168

169

170

171

172

173

174

175

176

177

178

179

180

181

182

183

184

185

186

187

188

assignment with similarities $>97 \%$ (Edgar, 2013). Taxonomic classification was conducted with Unite databases for fungi. The raw data of fungi were submitted to the NCBI with the SRA accession number: PRJNA494279.

The operational taxonomic identity was annotated using a BLAST algorithm against sequences within the Unite Database, using the QIIME software (Kõljalg et al., 2013). An OTU table was further generated to record the abundance of each OTU in each sample and the taxonomy of these OTUs. Operational taxonomic units (OTU)-level alpha diversity indices, such as Chao1 index (Chao, 2002), ACE index, Shannon index, and Simpson index, were computed using the OTU table in QIIME (Caporaso et al., 2010).

\section{Statistical analysis}

The shared and unique OTUs among samples were used to generate Venn diagrams using the R v3.3.2 (R Development Core Team, 2017) package with "VennDiagram", based on the occurrence of OTUs across sample (Zaura et al., 2009). The heatmap representation of the top 50 classified genera in per sample was built using the R v3.2.2 package with "gplot" and "pheatmap" (R Development Core Team, 2017). Non-metric multidimensional scaling (NMDS) with the BrayCurtis matrices was conducted the soil fungal community composition using the 'metaMDS' function in the Vegan package (Yang et al., 2017). The linear discriminant analysis (LDA) effect size (LEfSe) method were performed to detect potential biomarkers of abundant taxa based on a normalized relative abundance matrix across groups, using the default parameters, which was built using Galaxy based on the online interactive analysis of microflora data (Segata et al., 2011).

Differences in soil physicochemical characteristics, fungal alpha diversity indices, and the relative abundance of taxa (phyla and genus) of different forest soils were compared using oneway analysis of variance (ANOVA), which was followed by the least significant difference (LSD) test performed in IBM SPSS (version 19.0, Chicago, IL, USA) (Banerjee, 2016). In order to find the tree species affecting the soil quality, principal component analysis (PCA) were used to analyze all parameters via Canoco 4.5 (Braak \& Smilauer, 2002). Pearson correlation analysis was used to evaluate the correlations between soil fungal community diversity, fungal community composition 
189

190

191

192

193

194

195

196

197

198

199

200

201

202

203

204

205

206

207

208

209

210

\section{1}

212

213

214

215

and soil characteristics. Canonical correspondence analysis (CCA), which was performed via Canoco 4.5, was used to evaluate the linkages between dominant fungal groups and soil measured environmental factors (Braak \& Smilauer, 2002).

\section{Results}

\section{Soil physicochemical properties}

As seen in Table 2, soil $\mathrm{pH}$ value ranged from 4.89 to 5.70 . Soil $\mathrm{pH}$ value under $\mathrm{QM}$ was the most acidic with 4.89 , followed by $\mathrm{CB}$, while, JM contained the highest soil $\mathrm{pH}$ value. There were significant differences among different forest types regarding soil total $\mathrm{C}$ and total $\mathrm{N}$ contents $(\mathrm{F}$ $=112.275, P<0.001 ; \mathrm{F}=29.72, P<0.001$; Table 2). Interestingly, both total $\mathrm{C}$ and total $\mathrm{N}$ exhibited highest value in the soil of JM, with values of $100.53 \mathrm{~g} / \mathrm{kg}$ and $7.80 \mathrm{~g} / \mathrm{kg}$, but only 41.70 $\mathrm{g} / \mathrm{kg}$ and $3.58 \mathrm{~g} / \mathrm{kg}$ in the PK site, respectively. Soil $\mathrm{C} / \mathrm{N}$ values in all the treatments were below 25:1, among which $\mathrm{CB}$ had the highest $\mathrm{C} / \mathrm{N}$ with 13.81 . Available $\mathrm{N}$ was found in ranked order of $\mathrm{JM}>\mathrm{QM}>\mathrm{CB}>\mathrm{LG}>\mathrm{PK}$. There were also significant differences in total $\mathrm{P}$ among different forest types ( $\mathrm{F}=26.59, P<0.001$; Table 2), with the highest values under $\mathrm{CB}$ (Table 2).

The first two axes of the principal components analysis accounted for $96.9 \%$ of the total variance. The biplot showed a clear spatial separation among different revegetation types. In fact, the axis 1 discriminated for the PK situated in the first quadrant and JM, QM, and LG in third and fourth quadrant, while the axis 2 discriminated for PK and LG situated in the first and second quadrants and the JM, QM, and CM soils in the second and third quadrants. Also, the investigated soil characteristics were clearly separated in the quadrants (Fig. 2). The $\mathrm{C} / \mathrm{N}$ was situated in the first quadrant, soil total $\mathrm{C}$ and available $\mathrm{P}$ concentrations in the second quadrant, soil total $\mathrm{P}$ and total $\mathrm{N}$ in the third quadrant, and all other parameters were located in the fourth quadrant (Fig. 2).

\section{Fungal community diversity responses to different revegetation types}

Fungal $\alpha$-diversity varied greatly across the samples. The Shannon index, ACE index, Chao1 index, and Simpson index showed the highest values in the JM site, with 8.18, 879.57, 879.08, and 0.99 , respectively, followed by the $\mathrm{CB}$ site. The $\mathrm{ACE}$ index and Chao1 index were the lowest in the LG site, with 522.15 and 521.58, respectively, while, the Shannon index and Simpson index 
216

217

218

219

220

221

222

223

224

225

226

227

228

229

230

231

232

233

234

235

236

237

238

239

240

241

242

were the lowest in the QM site, with 5.79 and 0.89, respectively (Table 3). Pearson correlation analysis indicated that the Simpson index $(r=0.680, P<0.01)$ and Shannon index $(r=0.659, P<$ 0.01) were positively correlated with soil $\mathrm{pH}$, while the Shannon index was positively correlated with $\mathrm{C} / \mathrm{N}(r=0.528, P<0.05)$. In addition, ACE index and Chaol index were significantly positively correlated with total $\mathrm{C}(P<0.05), \mathrm{C} / \mathrm{N}$ and total $\mathrm{P}(P<0.01)$ (Table 4$)$.

\section{Fungal community structure responses to different revegetation types}

A total of 640,914 high-quality ITS sequences were obtained after the elimination of chimeras and sequences of low quality, with an average of 42,727 sequences being obtained in each soil sample.

At the phylum level, we found 8,875 fungal operational taxonomic units (OTUs) after quality filtering. On average, 592 OTUs were found in each sample. A maximum of 743 OTUs were detected in the CB site, however, only 455 OTUs were obtained in the LG site (Table 3). In order to determine rarefaction curves, richness, and diversity, 22, 716 reads were randomly selected from each sample. At the 3\% dissimilarity level (Fig. 3), the curve tended to flatten with the number of measured sequences increases, indicating that the experiment had obtained most of the sample information and had been able to reflect the fungal community composition of the forest soil.

The obtained sequences were affiliated with 15 phyla (including unknown). The dominant phyla, accounting for more than $1 \%$ of the overall communities, were Basidiomycota, Ascomycota, Zygomycota and Rozellomycota, with relative abundance values ranging from 21.31 to $66.08 \%, 24.82$ to $51.88 \%, 2.21$ to $6.37 \%$, and 0.42 to $2.09 \%$, respectively (Fig. 4). Phyla included Cercozoa, Chytridiomycota, Glomeromycota, and Ciliophora, which were less abundant ( $<1 \%$ of all classified sequences), but still were found in all of the examined soils. The relative abundances of these most abundant fungal phyla varied significantly among different forest types. The relative abundance of Ascomycota in JM was significantly higher than that of the other phyla, while the relative abundances of Basidiomycota was the lowest in JM. In the CB site, the relative abundance of Basidiomycota was highest, while, the relative abundances of Ascomycota and Rozellomycota were the lowest (Fig. 4).

At the genus level, the dominant genus, accounting for more than $1 \%$ of the overall 
243

244

245

246

247

248

249

250

251

252

253

254

255

256

257

258

259

260

261

262

263

264

265

266

267

268

269

communities, were Sebacina (5.95\%), Russula (4.38\%), Tomentella (3.74\%), Mortierella (2.97\%), Trechispora (2.17\%), Piloderma (1.92\%), Humicola (1.75\%), Suillus (1.69\%), Geminibasidium (1.65\%), Ramaria (1.62\%), Archaeorhizomyces (1.59\%), Cryptococcus (1.55\%), Simplicillium (1.50\%), Oidiodendron (1.37\%), Inocybe (1.32\%), Basidiobolus (1.20\%), and Bullera (1.07\%) (Fig. S1). Sebacina was the most abundant genus at PK, accounting for $21.17 \%$. The relative abundances of Russula showed highest in the CB than others (Fig. S1).

Venn diagrams were used to compare the fungal communities based on shared and unique OTUs among the samples. At the genus level, the Venn diagram showed 110 OTUs among the five forest types (Fig. 5). A total of 1,453, 1,006, 1,321, 1,143, and 1,742 OTUs were observed in the CB, LG, PK, QM and JM (Fig. 5).

To illustrate the fungal community structures of JM, QM, CB, LG, and PK, the heatmap analysis based on the top 50 most abundant fungal genera was used to intuitively display the differences in relative abundances of fungal OTUs among the samples (Fig. 6). The relative abundance of the soil fungal community from high to low is represented by red through black to green, reflecting the different compositions and relative abundances of soil fungi under different forest types. The genera Tomentella, Piloderma, Suillus, Oidiodendron, Inocybe, Entoloma, Cortinarius, Helvellosebacina, and Phaeoacremonium dominated in LG. While in CB, Russula, Trichoderma, Leucoagaricus, Amphinema, Umbelopsis, and Thelephora were the most dominated genera. Cladophialophora, Byssocorticium, Trichoderma, Hygrocybe, Exophiala, Leotia, and Knufia dominated in QM. Correspondingly, NMDS based Bray distance was carried out to show the distinct separation among different forest types (Fig. 7). By considering the phylogenetic relationship, the heatmap and NMDS plot elucidated that distinct variations of fungal community structure occurred among the different revegetation types, demonstrating the different effects of tree species on the fungal community composition following different revegetation types.

The LEfSe analysis was documented to determine the classified fungal taxa with significant abundance differences among the different sampling sites. As presented in Fig. 8, 16 fungal taxa were significantly different among the sites with LDA effect size scores were $>4.8$ (Fig. 8A), and 
270

271

272

273

274

275

276

277

278

279

280

281

282

283

284

285

286

287

288

289

290

291

292

293

294

295

296

5 fungal taxa were showed significantly different with LDA effect size scores were $>5.2$ (Fig. 8B). At the phylum level, the biomarkers were affiliated with Basidiomycota, and Ascomycota, respectively.

\section{Fungal community distribution as related to the soil properties}

Canonical correspondence analysis (CCA) was used to analyze the relative abundances of dominant fungal phyla constrained by soil properties (Fig. 9). The results showed that the cumulative interpretation variations of the first and second axes were 93.5\%, indicating that soil environmental factors greatly influenced the fungal community structure. At the phylum level (Fig. 9), soil $\mathrm{pH}(r=0.9104)$ and available $\mathrm{P}(r=0.6891)$ were significantly correlated with axis 1 , and the first axial interpretation rate was $69.1 \%$. The parameters $\mathrm{C} / \mathrm{N}(r=-0.7322)$ and total $\mathrm{P}(r=-$ 0.8094) were significantly related with axis2.

Pearson correlation analysis were used to explore the relationships between soil properties and the relative abundances of the 4 most abundant fungal phyla and 15 most abundant fungal genera. At the phylum level, the relative abundance of Basidiomycota was significantly negatively correlated with soil $\mathrm{pH}(r=-0.680, P<0.01)$ and available $\mathrm{P}(r=-0.611, P<0.01)$. Ascomycota relative abundance was positively correlated with total $\mathrm{C}(r=0.608, P<0.05)$, total $\mathrm{N}(r=0.655$, $P<0.01)$ and available $\mathrm{N}(r=0.693, P<0.01)$. Zygomycota relative abundance was positively correlated with $\mathrm{pH}(r=0.530, P<0.05)$ and available $\mathrm{P}(r=0.665, P<0.01)$. Rozellomycota relative abundance was significantly positively correlated with $\mathrm{pH}(r=0.716, P<0.01$; Table 5).

At the genus level, the abundance of Sebacina was significantly negatively correlated with total $\mathrm{C}(r=-0.563, P<0.05)$, total $\mathrm{N}(r=-0.533, P<0.05)$ and available $\mathrm{N}(r=-0.604, P<0.05)$. Russula was significantly positively correlated with $\mathrm{C} / \mathrm{N}(r=0.637, P<0.05)$ and total $\mathrm{P}(r=$ $0.751, P<0.01)$. While, Humicola was significantly positively correlated with total C $(r=0.745$, $P<0.01)$, total N $(r=0.735, P<0.01)$, and available N $(r=0.705, P<0.01)$. The relative abundance of Geminibasidium was significantly negatively correlated with total C $(r=-0.530, P$ $<0.05)$, total N $(r=-0.516, P<0.05)$, and available N $(r=-0.569, P<0.05)$. Archaeorhizomyces exhibited a positive correlation with $\mathrm{C} / \mathrm{N}(r=0.672, P<0.01)$ and total $\mathrm{P}(r=0.591, P<0.05)$. 
297 Cryptococcus abundance showed a significantly negative correlation with total $\mathrm{C}(r=-0.655, P<$ $2980.01)$, total N ( $r=-0.655, P<0.01)$, and available N $(r=-0.698, P<0.01)$. While, Simplicillium $299(r=0.540, P<0.05)$ and Bullera $(r=0.596, P<0.05)$ were significantly negatively correlated 300 with $\mathrm{pH}$.

\section{Discussion}

\section{Soil characteristics of the different revegetation types}

303 The soil nutrient concentrations ( $\mathrm{C}, \mathrm{N}$ and $\mathrm{P})$ we observed varied significantly among the different

304

305

306

307

308

309

310

311

312

313

314

315

316

317

318

319

320

321

322

323

revegetation types (Table 2). According to our findings, coniferous forests (LG, PK) and the conifer-broadleaf forest $(\mathrm{CB})$ had reduced soil total $\mathrm{C}$, total $\mathrm{N}$, and available $\mathrm{N}$ value compared with broadleaf forests (JM, QM), which was consistent with the study of Rahimabady et al. (2015). This influence may be attributed to different tree species with different litter quality and root exudates (Grayston \& Prescott, 2005). In our study, soil total C, total N, and available N in LG were higher than those of PK. A previous study has indicated that LG is a cold temperate deciduous coniferous forest with a higher litter amount. Despite the numerous recalcitrant substances found in the litter from LG site, such as lignin, resin, tannin, and wax, the dense coniferous litter covering the soil surface impedes air circulation, and accelerates the accumulation of soil nutrients. On the contrary, PK is often a component of warm evergreen coniferous forests; it produces relatively little litter, and its nutrient content in the soil is relatively low (Yang \& Han, 2001). Soil pH in this area ranged from 4.89 to 5.70, and compared to others, the soil under QM was most acidity, which might be associated with the litter quality. Compared to other broadleaf forests, the QM litter leaf quality is low, which has low nitrogen content, high $\mathrm{C} / \mathrm{N}$ ratio, higher lignin content, and higher lignin/N (Gao et al., 2016). Therefore, these are several factors contributing to the effect that soil $\mathrm{pH}$ under QM was lowest. In fact, it can be said that different tree species result in different soil characteristics under the same climatic conditions because of differences in litter quality and quantity (Jahed \& Hosseini, 2014), which was also observed in our study that the separation of the soils into four groups could depend on the fact that each one is mainly affected by certain soil characteristics (Fig. 2). Anyway, the forest types would seem to play an important role in 
324 regulating soil characteristics inside the same soil climate, and in particular, the difference between

325

326

327

328

329

330

331

332

333

334

335

336

337

338

339

340

341

342

343

344

345

346

347

348

349

350

between broadleaf forest and coniferous forest should be noted.

\section{Fungal community diversity and structure response to different revegetation types}

We documented that different forest revegetation types had distinct soil fungal community diversity and composition (Table 3, Fig. 4, Fig. S1), as reported by Myers et al. (2001). In our study, we observed that the average fungal Shannon index, ACE index, Chaol index and Simpson index were the highest in JM, followed by CB (Table 3), indicating that soil fungal richness and evenness indices in JM were the highest. The ACE index and Chao1 index were the lowest in the LG while, the Shannon index and Simpson index were the lowest in the QM. This finding may be attributed to the differences in the chemical composition and decomposition rate of litter (Bray et al., 2012), which modify soil physical and chemical properties and, consequently, alter the soil fungal diversity indices. These findings verified that the soil fungal diversity indices were affected by tree species following revegetation.

In terms of phyla and genera, the composition of fungal community did not significantly differ among the different revegetation types, however, the relative abundance values varied, probably as a result of different root residues and secretions produced by different tree species (Degrune et al., 2015). Although our research is limited due to the low number of replicates (three for each kind of revegetation forest), significant differences in fungal community relative abundance among different revegetation types were observed. The results of our comparison of soil fungal communities among different revegetation types revealed that the predominant taxa of fungal communities were the phylum Basidiomycota in the QM, CB, LG, and PK sites, followed by Ascomycota, Zygomycota and Rozellomycota (Fig. 4), which was consistent with the results from Gutianshan National Nature Reserve (Yu et al., 2013), and from Mount Nadu, southwestern China (Liu et al., 2018). Similar studies have also found such results (Leff et al., 2015; Yu et al., 2013). Basidiomycota tended to live in dry and cooler environments (Treseder et al., 2014), and the relative abundance of Basidiomycete in soils might be related to their ability to degrade of lignocellulose (Lundell et al., 2010), which were affected by dynamics of soil organic matter 
351 (Hannula et al., 2012). On the contrary, we observed that the relative abundance of Ascomycota, 352 over Basidiomycota, Zygomycota, and Rozellomycota, was predominant group in the JM, which 353 was in agreement with previous research (Curlevski et al., 2010). Findings from other tropical 354 regions indicated that in the broadleaf forests, Ascomycota was the most predominant phylum 355 (Kerfahi et al., 2014; Ritter et al., 2018). In our study, the higher abundance of Ascomycota in JM 356 suggested the enrichment of saprotrophic species, proving that Ascomycota tend to use the easily 357 degradable residues (Lundell et al., 2010), which might be related to organic matter input (Lundell et al., 2010). However, the finding from Yarraman showed that Zygomycota was the dominant phylum (He et al., 2010). These disparate results may indicate that both environmental filtering and niche differentiation determine the global distributions of soil fungi (Bahram et al., 2018).

The dominant fungal genera (Sebacina, Russula, Tomentella) were representative of the dominant genera found in our study (Fig. S1), which was accordant with previous research (Welc et al. 2014). Sebacina was the most common genus in our study, and previous studies have put forward that Sebacina could help its host plant to overcome biotic and abiotic stresses by supplying it with water and nutrients (Gao \& Yang, 2016). Based on previous research, Tomentella has been reported to be distributed throughout the world (Kõljalg et al., 2000), which was also the common genus in our study. The influence of different revegetation types on the soil fungal community is often related to the nature and quantity of organic matter returned by plant litter, which provides major resources for soil microorganisms (Saetre \& Bååth, 2000; Wardle et al., 2004).

The results of clear differentiation in the heatmap (Fig. 6) and NMDS (Fig. 7) plots illustrated that distinct differences in the fungal communities were observed in different revegetation types, suggesting that broad-leaved forests and coniferous forests each owned different fungal community. Our results were agreement with previous study which have established that the composition of the soil fungal community in natural forest differed from those in the hoop pine plantation (Lin et al., 2011). These findings confirmed that revegetation with different tree species altered the soil fungal community diversity and composition. The significant contribution of different forest types for shaping the soil fungal community has been established by previous 
378 findings (Sun et al., 2016).

379 Relationship between fungal communities and soil environmental factors

380 Soil environmental factors demonstrated remarkable relationships with fungal diversity. The 381 Simpson index and Shannon index were positively correlated with $\mathrm{pH}$ (Table 4). Similar results 382 have been reported previously (Djukic et al., 2014; Liu et al., 2018; Wang et al., 2015) that the 383 diversity of the fungal community increased with soil $\mathrm{pH}$ value. In our study, soil Chao1 index, 384 ACE index, and Shannon index significantly increased with the increasing C/N ratios (Table 4). In addition, ACE index and Chaol index were significantly positively correlated with total $\mathrm{P}$ (Table 4), which was in accordance with a previous study reporting that fungal diversity is significantly affected by soil P-related factors (Liu et al., 2018).

Just as the soil fungal diversity, soil environmental factors had greatly influenced on the fungal community composition. Previous studies have shown that soil physicochemical properties, such as soil moisture (Brockett et al., 2012), soil pH (Rousk et al., 2010), available soil nutrients (Lauber et al., 2008), soil total $\mathrm{C}$ (Yang et al., 2014), and C/N ratio (Christianl et al., 2008), strongly affected fungal communities. Moreover, our study also confirmed that the abundances of the most dominant fungal communities were significantly correlated with soil $\mathrm{pH}$ value. In addition, total $\mathrm{C}$, total $\mathrm{N}$, available $\mathrm{N}$, and available $\mathrm{P}$ were also closely linked to the fungal community composition (Fig. 9, Table 5), which was consistent with other researches (Sun et al., 2016; Zhang et al., 2017). Basidiomycota are generally sensitive to physic-chemical characteristic disturbance (Osono, 2007). In our study, the relative abundances of Basidiomycota was significantly negatively correlated with $\mathrm{pH}$ and available $\mathrm{P}$, which was in contrast to the findings of previous studies (Tedersoo et al., 2014; Tian et al., 2017). In a previous study, soil with higher relative abundance of Ascomycetes has a higher pH value (Lauber et al., 2008). However, in our study, Ascomycota was not correlated with soil $\mathrm{pH}$ value. A relatively small $\mathrm{pH}$ range (4.89 to 5.70) was observed in our study, which might be difficult to ascertain such a correlation. Interestingly, the 403 relative abundance of Ascomycota was positively correlated with total $\mathrm{C}$, total $\mathrm{N}$ and available $\mathrm{N}$. 
405 (Sterkenburg et al., 2015). In our research, the abundance of Zygomycota was positively correlated 406 with available $\mathrm{P}$. This leads us to infer that soil available $\mathrm{P}$ was an important regulator of fungal 407 communities, which is consistent with the findings of Dang et al. (2017). These results indicated 408 that differential responses of soil fungal community composition to the different revegetation types 409 largely dependent on soil physicochemical characteristics, highlighting the decisive role of soil 410 physicochemical variables in altering fungal communities during vegetation restoration, which has 411 also been stated previously (Kuramae et al., 2010)

\section{Conclusions}

413 Our results here showed that the different revegetation types would seem to play an important role 414 in regulating soil characteristics in the same climate, especially between broadleaf forest and 415 coniferous forest, which generated shifts in soil fungal community diversity and composition. 416 Basidiomycota, Ascomycota, Zygomycota and Rozellomycota were the predominant fungal 417 community in Baishilazi Nature Reserve, and the relative abundances of these abundant fungal 418 phyla varied significantly among the different revegetation types. The average Shannon index, 419 ACE index, Chaol index and Simpson index were highest in JM. The abundances of the most 420 dominant fungal communities correlated significantly with soil $\mathrm{pH}$, total $\mathrm{C}$, total $\mathrm{N}$, available $\mathrm{N}$, 421 and available $P$.

$422-$

\section{References}

424 Bahram M, Põlme S, Kõljalg U, Zarre S, Tedersoo L. 2012. Regional and local patterns of ectomycorrhizal fungal diversity and community structure along an altitudinal gradient in the Hyrcanian forests of northern Iran. New Phytologist 193(2): 465-473 DOI 10.1111/j.14698137.2011.03927.x.

Bahram M, Hildebrand F, Forslund SK, Hildebrand F, Forslund SK, Anderson JL, Soudzilovskaia NA, Bodegom PM, Bengtsson-Palme J, Anslan S, Coelho LP, Harend H, Huerta-Cepas J, Medema MH, Maltz MR, Mundra S, Olsson PA, Pent M, Põlme S, Sunagawa S, Ryberg M, Tedersoo L, Bork P. 2018. Structure and function of the global topsoil microbiome. Nature 
560: 233-237 DOI 10.1038/s41586-018-0386-6.

Banerjee S. 2016. Network analysis reveals functional redundancy and keystone taxa amongst bacterial and fungal communities during organic matter decomposition in an arable soil. Soil Biology and Biochemistry 97:188-198 DOI org/10.1016/j.soilbio.2016.03.017.

Bao SD. 2000. Soil and Agricultural Chemistry Analysis. Beijing: China Agriculture Press.

Benayas JMR, Bullock JM. 2009. Enhancement of biodiversity and ecosystem services by ecological restoration: a meta-analysis. Science 325(5944): 1121-1124 DOI $10.1126 /$ science. 1172460

Braak CJFT, Smilauer P. 2002. CANOCO Reference Manual and CanoDraw for Windows User's Guide: Software for Canonical Community Ordination (version 4.5). Ithaca Ny Usa Www.

Bray SR, Kitajima K, Mack MC. 2012. Temporal dynamics of microbial communities on decomposing leaf litter of 10 plant species in relation to decomposition rate. Soil Biology and Biochemistry 49(1): 30-37 DOI 10.1016/j.soilbio.2012.02.009.

Brockett BFT, Prescott CE, Grayston SJ. 2012. Soil moisture is the major factor influencing microbial community structure and enzyme activities across seven biogeoclimatic zones in western Canada. Soil Biology and Biochemistry 44(1): 9-20 DOI org/10.1016/j.soilbio.2011.09.003.

Caporaso JG, Kuczynski J, Stombaugh J, Bittinger K, Bushman FD, Costello EK, Fierer N, Peña AG, Goodrich JK, Gordon JI, Huttley GA, Kelley ST, Knights D, Koenig JE, Ley RE, Lozupone CA, McDonald D, Muegge BD, Pirrung M, Reeder J, Sevinsky JR, Turnbaugh PJ, Walters WA, Widmann J, Yatsunenko T, Zaneveld J, Knight R. 2010. QIIME allows analysis of highthroughput community sequencing data. Nat Methods 7(5): 335-336 DOI 10.1038/nmeth.f.303.

Chao A, Bunge J. 2002. Estimating the number of species in a stochastic abundance model. Biometrics 58(3): 531-539 DOI 10.1111/j.0006-341X.2002.00531.x.

Chen X, Sun XD, Bi SY, Lu GZ. 2010. Fungi diversity of ginseng rhizosphere soil in northeastern China. Agricultural Science and Technology-Hunan 11(2): 132-136. 
459

460

461

462

463

464

465

466

467

468

469

470

471

472

473

474

475

476

477

478

479

480

481

482

483

484

485

Cheng F, Peng X, Zhao P, Zhong C, Cheng Y, Cui C, Zhang S. 2013. Soil Microbial Biomass, Basal respiration and enzyme activity of main forest types in the Qinling Mountains. Plos One 8(6): e67353 DOI 10.1371/journal.pone.0067353.

Christianl L, Michaels S, Marka B, Fierer N. 2008. The influence of soil properties on the structure of bacterial and fungal communities across land-use types. Soil Biology and Biochemistry, 40(9): 2407-2415 DOI org/10.1016/j.soilbio.2008.05.021.

Collen B, Nicholson E. 2014. Conservation. Taking the measure of change. Science 346(6206): 166-167 DOI 10.1126/science.1255772.

Curlevski NJA, Xu ZH, Anderson IC, Cairney JWG. 2010. Soil fungal communities differ in native mixed forest and adjacent Araucaria cunninghamii plantations in subtropical Australia. Journal of Soils and Sediments 10(7): 1278-1288 DOI org/10.1007/s11368-0100239-x.

Dang P, Yu X, Le H, Liu J, Shen Z, Zhao Z. 2017. Effects of stand age and soil properties on soil bacterial and fungal community composition in Chinese pine plantations on the Loess Plateau. Plos One 12(10): e0186501 DOI 10.1371/journal.pone.0186501.

Degrune F, Dufrêne M, Colinet G, Massart S, Taminiau B, Bodson B, Hiel MP, Daube G, Carine N, Vandenbol M. 2015. A novel sub-phylum method discriminates better the impact of crop management on soil microbial community. Agronomy for Sustainable Development 35(3): 1157-1166 DOI 10.1007/s13593-015-0291-4.

Devi LS, Khaund P, Nongkhlaw FMW, Joshi SR. 2012. Diversity of culturable soil micro-fungi along altitudinal gradients of Eastern Himalayas. Mycobiology 40(3): 151-158 DOI 10.5941/MYCO.2012.40.3.151.

Dickie IA, Xu B, Koide RT. 2002. Vertical niche differentiation of ectomycorrhizal hyphae in soil as shown by T-RFLP analysis. New Phytologist 156(3): 527-535 DOI 10.1046/j.14698137.2002.00535.x.

Dickie IA. 2007. Host preference, niches and fungal diversity. New Phytologist 174(2): 230-233 DOI 10.1111/j.1469-8137.2007.02055.x. 
486

487

488

489

490

491

492

493

494

495

496

497

498

499

500

501

502

503

504

505

506

507

508

509

510

511

512

Djukic I, Zehetner F, Mentler A, Gerzabek MH. 2010. Microbial community composition and activity in different Alpine vegetation zones. Soil Biology and Biochemistry 42(2): 155-161 DOI org/10.1016/j.soilbio.2009.10.006.

Dosskey MG, Bentrup G, Schoeneberger M. 2012. A role for agroforestry in forest restoration in the lower Mississippi Alluvial Valley. Journal of Forestry 110(1): 48-55 DOI 10.5849/jof.10061.

Edgar RC. 2013. UPARSE: highly accurate OTU sequences from microbial amplicon reads. Nature Methods 10(10): 996-998 DOI 10.1038/nmeth.2604.

Emteryd O. 1989. Chemical and physical analysis of inorganic nutrients in plant, soil, water and air. Swedish University of Agricultural Sciences. Department of Forest Site Research.

Fan A, Liu F. 2014. Seasonal Variations of Soil Microbial Biomass and Its Influence on Soil Microbial Respiration in Secondary Forest Communities in Montane Region of Eastern Liaoning Province. Journal of Northeast Forestry University (3):99-102 DOI 10.13759/j.cnki.dlxb.2014.03.023.

Fierer N, Jackson JA, Vilgalys R, Jackson RB. 2005. Assessment of soil microbial community structure by use of taxon-specific quantitative PCR assays. Applied and Environmental Microbiology 71(7):4117-4120 DOI 10.1128/AEM.71.7.4117-4120.2005.

Frey SD, Knorr M, Parrent JL, Simpson RT. 2004. Chronic nitrogen enrichment affects the structure and function of the soil microbial community in temperate hardwood and pine forests. Forest Ecology and Management 196(1):159-171 DOI org/10.1016/j.foreco.2004.03.018.

Fulé PZ, Crouse JE, Roccaforte JP, Kalies EL. 2012. Do thinning and/or burning treatments in western USA ponderosa or Jeffrey pine-dominated forests help restore natural fire behavior? Forest Ecology and Management, 269(269): 68-81 DOI 10.1016/j.foreco.2011.12.025.

Gao Q, Yang ZL. 2016. Diversity and distribution patterns of root-associated fungi on herbaceous plants in alpine meadows of southwestern China. Mycologia 108(2):281-291.

Gao Y, Qiu GY, Shimizu H, Tobe K, Sun B, Wang J. 2002. A 10-Year study on techniques for 
513

514

515

516

517

518

519

520

521

522

523

524

525

526

527

528

529

530

531

532

533

534

535

536

537

538

539

vegetation restoration in a desertified salt Lake Area. Journal of Arid Environments 52(4): 483-497 DOI org/10.1006/jare.2002.1013.

Gardes M, Bruns TD. 1993. ITS primers with enhanced specificity for basidiomycetes-application to the identification of mycorrhizae and rusts. Molecular ecology 2(2): 113-118 DOI 10.1111/j.1365-294X.1993.tb00005.x.

Geml J, Pastor N, Fernandez L, Pacheco S, Semenova TA, Becerra AG, Wicaksono CY, Nouhra ER. 2014. Large-scale fungal diversity assessment in the Andean Yungas forests reveals strong community turnover among forest types along an altitudinal gradient. Molecular ecology 23(10): 2452-2472 DOI 10.1111/mec. 12765.

Georgiadis P, Vesterdal L, Stupak I, Raulund-Rasmussen K. 2017. Accumulation of soil organic carbon after cropland conversion to short-rotation willow and poplar. GCB Bioenergy 9(8): 1390-1401 DOI 10.1111/gcbb.12416

Girvan MS, Bullimore J, Pretty JN, Osborn AM, Ball AS. 2003. Soil Type Is the Primary Determinant of the Composition of the Total and Active Bacterial Communities in Arable Soils. Applied and Environmental Microbiology 69(3): 1800-1809 DOI 10.1128/AEM.69.3.1800-1809.2003.

Grayston SJ, Prescott CE. 2005. Microbial communities in forest floors under four tree species in coastal British Columbia. Soil Biology and Biochemistry 37(6): 1157-1167 DOI 10.1016/j.soilbio.2004.11.014.

Guo Y, Chen X, Wu Y, Zhang L, Cheng J, Wei G, Lin Y. 2018. Natural revegetation of a semiarid habitat alters taxonomic and functional diversity of soil microbial communities. Science of the Total Environment 635: 598-606 DOI 10.1016/j.scitotenv.

Hannula SE, Boschker HTS, Boer WD, Veen JAV. 2012. ${ }^{13} \mathrm{C}$ pulse-labeling assessment of the community structure of active fungi in the rhizosphere of a genetically starch-modified potato (Solanum tuberosum) cultivar and its parental isoline. New Phytologist 194(3): 784-799 DOI 10.1111/j.1469-8137.2012.04089.x.

Harris J. 2009. Soil microbial communities and restoration ecology: facilitators or followers? 
Science 325(5940): 573-574 DOI 10.1126/science.1172975.

541

542

543

544

545

546

547

548

549

550

551

552

553

554

555

556

557

558

559

560

561

562

563

564

565

566

Harrison KA, Bardgett RD. 2010. Influence of plant species and soil conditions on plant-soil feedback in mixed grassland communities. Journal of Ecology 98(2): 384-395 DOI 10.1111/j.1365-2745.2009.01614.x.

Hatakka A. 2010. Lignin-modifying enzymes from selected white-rot fungi: production and role from in lignin degradation. Fems Microbiology Reviews 13(2-3): 125-135 DOI 10.1111/j.1574-6976.1994.tb00039.x.

He J, Xu Z, Hughes J. 2005. Analyses of soil fungal communities in adjacent natural forest and hoop pine plantation ecosystems of subtropical Australia using molecular approaches based on 18S rRNA genes. Fems Microbiology Letters, 247(1): 91-100 DOI 10.1016/j.femsle.2005.04.033.

Herrera Paredes S, Lebeis SL. 2016. Giving back to the community: microbial mechanisms of plant-soil interactions. Functional Ecology 30(7): 1043-1052 DOI 10.1111/j.13652435.12684 .

Jahed RR, Hosseini SM. 2014. The effect of natural and planted forest stands on soil fertility in the Hyrcanian region, Iran. Biodiversitas Journal of Biological Diversity, 15(2): 206-214. DOI 10.13057/biodiv/d150213.

Jangid K, Whitman WB, Condron LM, Turner BL, Williams MA. 2013. Soil bacterial community succession during long-term ecosystem development. Molecular Ecology 22(12): 3415-3424 DOI $10.1111 / \mathrm{mec} .12325$.

Jin Z, Li X, Wang Y, Wang K, Cui B. 2016. Comparing watershed black locust afforestation and natural revegetation impacts on soil nitrogen on the Loess Plateau of China. Scientific Reports 6(25048): 25048 DOI 10.1038/srep25048.

Kerfahi D, Tripathi BM, Lee J, Edwards DP, Adams JM. 2014. The Impact of Selective-Logging and Forest Clearance for Oil Palm on Fungal Communities in Borneo. Plos One 9(11): e111525 DOI 10.1371/journal.pone.0111525.

Kernaghan G, Harper KA. 2001. Community structure of ectomycorrhizal fungi across an 
567

568

569

570

571

572

573

574

575

576

577

578

579

580

581

582

583

584

585

586

587

588

589

590

591

592

593

alpine/subalpine ecotone. Ecography 24(2): 181-188 DOI $10.1034 / \mathrm{j} .1600-$ 0587.2001.240208.x.

Koljalg U, Afs T, Larsson EHN, Larsson E, Hallenberg N, Stenlid J, Larsson KH, Fransson PM, Kårén O, Jonsson L. 2010. Diversity and abundance of resupinate thelephoroid fungi as ectomycorrhizal symbionts in Swedish boreal forests. Molecular Ecology 9(12): 1985-1996 DOI org/10.1046/j.1365-294X.2000.01105.x.

Kõljalg U, Nilsson RH, Abarenkov K, Tedersoo L, Taylor AF, Bahram M, Bates ST, Bruns TD, Bengtsson-Palme J, Callaghan TM, Douglas B, Drenkhan T, Eberhardt U, Dueñas M, Grebenc T, Griffith GW, Hartmann M, Kirk PM, Kohout P, Larsson E, Lindahl BD, Lücking R, Martín MP, Matheny PB, Nguyen NH, Niskanen T, Oja J, Peay KG, Peintner U, Peterson M, Põldmaa K, Saag L, Saar I, Schüßler A, Scott JA, Senés C, Smith ME, Suija A, Taylor DL, Telleria MT, Weiss M, Larsson KH. 2013. Towards a unified paradigm for sequencebased identification of fungi. Molecular Ecology 22(21): 5271-5277 DOI $10.1111 / \mathrm{mec} .12481$.

Kuramae EE, Gamper HA, Yergeau E, Piceno YM, Brodie EL, Desantis TZ, Andersen GL, van Veen JA, Kowalchuk GA. 2010. Microbial secondary succession in a chronosequence of chalk grasslands. Isme Journal 4(5): 711 DOI org/10.1038/ismej.2010.11.

Lauber CL, Strickland MS, Bradford MA, Fierer N. 2008. The influence of soil properties on the structure of bacterial and fungal communities across land-use types. Soil Biology and Biochemistry 40(9): 2407-2415 DOI org/10.1016/j.soilbio.2008.05.021.

Leff JW, Jones SE, Prober SM, Barberán A, Borer ET, Firn JL, Harpole WS, Hobbie SE, Hofmockel KS, Knops JM, McCulley RL, La Pierre K, Risch AC, Seabloom EW, Schütz M, Steenbock C, Stevens CJ, Fierer N. 2015. Consistent responses of soil microbial communities to elevated nutrient inputs in grasslands across the globe. Proceedings of the National Academy of Sciences of the United States of America 112(35): 10967-10972 DOI 10.1073/pnas.1508382112.

Liu D, Liu G, Li C, Wang J, Zhang L. 2018. Soil pH determines fungal diversity along an elevation 
594

595

596

597

598

599

600

601

602

603

604

605

606

607

608

609

610

611

612

613

614

615

616

617

618

619

620

gradient in Southwestern China. Science China Life Sciences (6): 1-9 DOI 10.1007/s11427017-9200-1.

Liu M, Liu J, Chen X, Jiang C, Wu M, Li ZP. 2018 Shifts in bacterial and fungal diversity in a paddy soil faced with phosphorus surplus. Biology and Fertility of Soils 54(2): 259-267 DOI 10.1007/s00374-017-1258-1.

Liu J, Diamond J. 2005. China's environment in a globalizing world. Nature, 435(7046): 11791186 DOI 10.1038/4351179a.

Lovett GM, Weathers KC, Arthur MA, Schultz JC. 2004. Nitrogen cycling in a northern hardwood forest: do species matter. Biogeochemistry 67(3): 289-308 DOI 10.1023/B:BIOG.0000015786.65466.f5.

Lundell TK, Makela MK. 2010. Lignin-modifying enzymes in filamentous basidiomycetes-ecological, functional and phylogenetic review. Journal of Basic Microbiology 50(1): 5-20 DOI 10.1002/jobm.200900338.

Myers RT, Zak DR, White DC, Peacock A. 2001. Landscape-Level Patterns of Microbial Community Composition and Substrate Use in Upland Forest Ecosystems. Soil Science Society of America Journal 65(2): 359-367 DOI 10.2136/sssaj2001.652359x.

Ni Y, Yang T, Zhang K, Shen C, Chu H. 2018. Fungal Communities Along a Small-Scale Elevational Gradient in an Alpine Tundra Are Determined by Soil Carbon Nitrogen Ratios. Frontiers in Microbiology 9: 01815 DOI org/10.3389/fmicb.2018.01815.

Nunezmir GC, Iannone BVI, Curtis K, Fei S. 2015. Evaluating the evolution of forest restoration research in a changing world: a "big literature" review. New Forests 46(5-6): 669-682 DOI 10.1007/s11056-015-9503-7.

Osono T. 2007. Ecology of ligninolytic fungi associated with leaf litter decomposition. Ecological Research 22(6): 955-974 DOI 10.1007/s11284-007-0390-z.

Parkinson JA, Allen SE. 2009. A wet oxidation procedure suitable for the determination of nitrogen and mineral nutrients in biological material. Communications in Soil Science and Plant Analysis 6(1): 1-11 DOI org/10.1080/00103627509366539. 
621 Peter M, Ayer F, Egli S. 2001. Nitrogen addition in a Norway spruce stand altered macromycete 622 sporocarp production and below-ground ectomycorrhizal species composition. New 623 Phytologist 149(2): 311-325 DOI 10.1046/j.1469-8137.2001.00030.x.

624 Qi JH. 2017. Contents of soil organic carbon and its relations with physicochemical properties of 625 secondary natural oak forests in Eastern Mountain Area of Liaoning Province. Journal of Soil 626 and Water Conservation 31(4): 135-140 DOI 10.13870/j.cnki.stbcxb.2017.04.022.

627

Rahimabady MS, Akbarinia M, Kooch Y. 2015. The effect of land covers on soil quality properties in the Hyrcanian regions of Iran. Journal of Bioscience and Biotechnology 4(1): 73-79.

R Development Core Team. 2017. R: A language and environment for statistical computing. R Foundation for Statistical Computing, Vienna, Austria.

Ren C, Zhao F, Kang D, Yang G, Han X, Tong X, Feng Y, Ren GX. 2016. Linkages of C:N:P stoichiometry and bacterial community in soil following afforestation of former farmland. Forest Ecology and Management 376: 59-66 DOI 10.1016/j.foreco.2016.06.004.

Ritter CD, Zizka A, Barnes C, Nilsson RH, Roger F, Antonelli A. 2018. Locality or habitat? Exploring predictors of biodiversity in Amazonia. Ecography 41: 1-13 DOI org/10.1111/ecog.03833.

Rousk J, Bååth E, Brookes PC, Lauber CL, Lozupone C, Caporaso JG, Knight R, Fierer N. 2010. Soil bacterial and fungal communities across a $\mathrm{pH}$ gradient in an arable soil. Isme Journal Multidisciplinary Journal of Microbial Ecology 4(10): 1340-1351 DOI10.1038/ismej.2010.58.

Saetre P, Bååth E. 2000. Spatial variation and patterns of soil microbial community structure in a mixed spruce-birch stand. Soil Biology and Biochemistry 32(7): 909-917 DOI 10.1016/S0038-0717(99)00215-1.

Schrumpf M, Schulze ED, Kaiser K, Schumacher, J. 2011. How accurately can soil organic carbon stocks and stock changes be quantified by soil inventories? Biogeosciences Discussions 8(1): 1193-1212 DOI org/10.5194/bg-8-1193-2011.

Segata N, Izard J, Waldron L, Gevers D, Miropolsky L, Garrett WS, Huttenhower C. 2011. 
648

649

650

651

652

653

654

655

656

657

658

659

660

661

662

663

664

665

666

667

668

669

670

671

672

673

674

Metagenomic biomarker discovery and explanation. Genome Biology 12(6): R60 DOI 10.1186/gb-2011-12-6-r60.

Sterkenburg E, Bahr A, Clemmensen KE, Clemmensen KE, Lindahl BD. 2015. Changes in fungal communities along a boreal forest soil fertility gradient. New Phytologist 207(4): 1145-1158 DOI 10.1111/nph.13426.

Sun H, Terhonen E, Kovalchuk A, Tuovila H, Chen H, Oghenekaro AO, Heinonsalo J, Kohler A, Kasanen R, Vasander H, Asiegbu FO. 2016. Dominant tree species and soil type affect fungal community structure in a boreal peatland forest. Applied and Environmental Microbiology 82(9): 2632 DOI 10.1128/AEM.03858-15.

Tedersoo L, Bahram M, Põlme S, U Kõljalg, Yorou NS, Wijesundera R, Ruiz LV, Vasco-Palacios AM., Thu PQ, Suija A, Smith ME, Sharp C, Saluveer E, Saitta A, Rosas M, Riit T, Ratkowsky D, Pritsch K, Põldmaa K, Piepenbring M, Phosri C, Peterson M, Parts K, Pärtel K, Otsing E, Nouhra E, Njouonkou AL, Nilsson RH, Morgado LN, Mayor J, May TW, Majuakim L, Lodge DJ, Lee SS, Larsson KH, Kohout P, Hosaka K, Hiiesalu I, Henkel TW, Harend H, Guo LD, Greslebin A, Grelet G, Geml J, Gates G, Dunstan W, Dunk C, Drenkhan R, Dearnaley J, Kesel AD, Dang T, Chen X, Buegger F, Brearley FQ, Bonito G, Anslan S, Abell S, Abarenkov K. 2014. Global diversity and geography of soil fungi. Science 346(6213): 1-11 DOI 10.1126/science.1256688.

Tian Q, Taniguchi T, Shi WY, Li GQ, Yamanaka N, Du S. 2017. Land-use types and soil chemical properties influence soil microbial communities in the semiarid Loess Plateau region in China. Scientific Reports 7(7): 45289 DOI 10.1038/srep45289.

Treseder KK, Maltz MR, Hawkins BA, Fierer N, Stajich JE, McGuire KL. 2014. Evolutionary histories of soil fungi are reflected in their large-scale biogeography. Ecology Letters 17(9): 1086-93 DOI 10.1111/ele.12311.

Van DHMGA, Bardgett RD, Van Straalen NM. 2010. The unseen majority: soil microbes as drivers of plant diversity and productivity in terrestrial ecosystems. Ecology Letters 11(3): 296-310 DOI 10.1111/j.1461-0248.2007.01139.x. 
675 Waldrop MP, Zak DR, Blackwood CB, Curtis CD, Tilman D. 2006. Resource availability controls 676 fungal diversity across a plant diversity gradient. Ecology Letters 9(10): 1127-1135 DOI $677 \quad 10.1111 / \mathrm{j} .1461-0248.2006 .00965 . x$.

678 Wallander H, Johansson U, Sterkenburg E, Brandstrcem DM, Lindahl BD. 2010. Production of 679 ectomycorrhizal mycelium peaks during canopy closure in Norway spruce forests. New 680 Phytologist 187(4): 1124-1134 DOI 10.1111/j.1469-8137.2010.03324.x.

Wang JT, Zheng YM, Hu HW, Zhang LM, Li J, He JZ. 2015. Soil pH determines the alpha diversity but not beta diversity of soil fungal community along altitude in a typical Tibetan forest ecosystem. Journal of Soils and Sediments 15(5): 1224-1232 DOI 10.1007/s11368015-1070-1.

Wardle DA; Bardgett RD; Klironomos JN, Setälä H, van der Putten WH, Wall DH. 2004. Ecological linkages between aboveground and belowground biota. Science 304(5677): 16291633 DOI 10.1126/science. 1094875.

Weand MP, Arthur MA, Lovett GM, Sikora F, Weathers KC. 2010. The phosphorus status of northern hardwoods differs by species but is unaffected by nitrogen fertilization. Biogeochemistry 97(2-3): 159-181 DOI 10.1007/s10533-009-9364-2.

Welc M, Frossard E, Egli S, Bünemann EK, Jansa J. 2014. Rhizosphere fungal assemblages and soil enzymatic activities in a 110-years alpine chronosequence. Soil Biology and Biochemistry 74: 21-30 DOI org/10.1016/j.soilbio.2014.02.014.

White TJ, Bruns T, Lee S, Taylor J. 1990. Amplification and direct sequencing of fungal ribosomal RNA genes for phylogenetics. PCR protocols: a guide to methods and applications 18(1): 315-322.

Wu G, Liu Y, Fang N, Deng L, Shi Z. 2016. Soil physical properties response to grassland conversion from cropland on the semia arid area. Ecohydrology 9(8): 1471-1479 DOI 10.1002/eco.1740.

Xiao X, Wei X, Liu Y, Ouyang X, Li Q, Ning J. 2015. Aerial Seeding: An Effective Forest Restoration Method in Highly Degraded Forest Landscapes of Sub-Tropic Regions. Forests 
703

704

705

706

707

708

709

710

711

712

713

714

715

716

717

718

719

720

721

722

723

724

725

726

727

728

Yan DF, Mills JG, Gellie NJC, Bissett A, Lowe AJ, Breed MF. 2018. High-throughput eDNA monitoring of fungi to track functional recovery in ecological restoration. Biological Conservation, 217: 113-120 DOI 10.1016/j.biocon.2017.10.035.

Yang XQ, Han YZ. 2001. Spatial variations of soil organic carbon and nitrogen of forest land in Guandi Mountain. Forest research 24 (2): 223-229.

Yang W, Guo Y, Wang X, Pelletier F. 2017. Temporal variations of soil microbial community under compost addition in black soil of Northeast China. Applied Soil Ecology 121: 214-222 DOI org/10.1016/j.apsoil.2017.10.005.

Yang Y, Gao Y, Wang S, Xu D, Yu H, Wu L, Lin Q, Hu Y, Li X, He Z, Deng Y, Zhou J. 2014. The microbial gene diversity along an elevation gradient of the Tibetan grassland. Isme Journal 8(2): 430-440 DOI 10.1038/ismej.2013.146.

You Y, Wang J, Huang X, Tang Z, Liu S, Sun OJ. 2014. Relating microbial community structure to functioning in forest soil organic carbon transformation and turnover. Ecology and Evolution 4(5): 633-647 DOI 10.1002/ece3.969.

Yu TW, Wubet T, Trogisch S, Both S, Scholten T, Bruelheide H, Buscot F. 2013. Forest Age and Plant Species Composition Determine the Soil Fungal Community Composition in a Chinese Subtropical Forest. Plos One 8(6): e66829 DOI 10.1371/journal.pone.0066829.

Zaura E, Keijser BJF, Huse SM, Crielaard W. 2009. Defining the healthy" core microbiome" of oral microbial communities. BMC microbiology 9(1): 259 DOI 10.1186/1471-2180-9-259.

Zhang H, You W, Wei W, Zhou M. 2017. Soil physical and chemical properties and correlation with organic carbon in original Korean pine forest in Eastern Liaoning mountainous area. $\begin{array}{llllllll}\text { Journal of Northwest A } & \& & F & \text { University, } & 45 & \text { (1): } & 76-82 & \text { DOI }\end{array}$ 10.13207/j.cnki.jnwafu.2017.01.01

Zhang Q, Jia X, Zhao C, Shao M. 2018. Revegetation with artificial plants improves topsoil hydrological properties but intensifies deep-soil drying in northern Loess Plateau, China. Journal of Arid Land (3):1-12 DOI org/10.1007/s40333-018-0007-0. 
729 Zhang Z, Zhou X, Tian L, Ma L, Luo S, Zhang J, Li X, Tian C. 2017. Fungal communities in 730 ancient peatlands developed from different periods in the Sanjiang Plain, China. Plos One 731 12(12): e0187575 DOI 10.1371/journal.pone.0187575.

732 Zhong Y, Yan W, Shangguan Z. 2015. Impact of long-term N additions upon coupling between 733 soil microbial community structure and activity, and nutrient-use efficiencies. Soil Biology 734 and Biochemistry, 91: 151-159 DOI 10.1016/j.soilbio.2015.08.030.

735 Zhu W, Cai X, Liu X, Wang JX, Cheng S, Zhang XY, Li DY, Li MH. 2010. Soil microbial 736 population dynamics along a chronosequence of moist evergreen broad-leaved forest 737 succession in southwestern China. Journal of Mountain Science 7(4): 327-338 DOI $738 \quad 10.1007 / \mathrm{s} 11629-010-1098-\mathrm{z}$. 
Figure 1

Map showing sampling location of the study. 


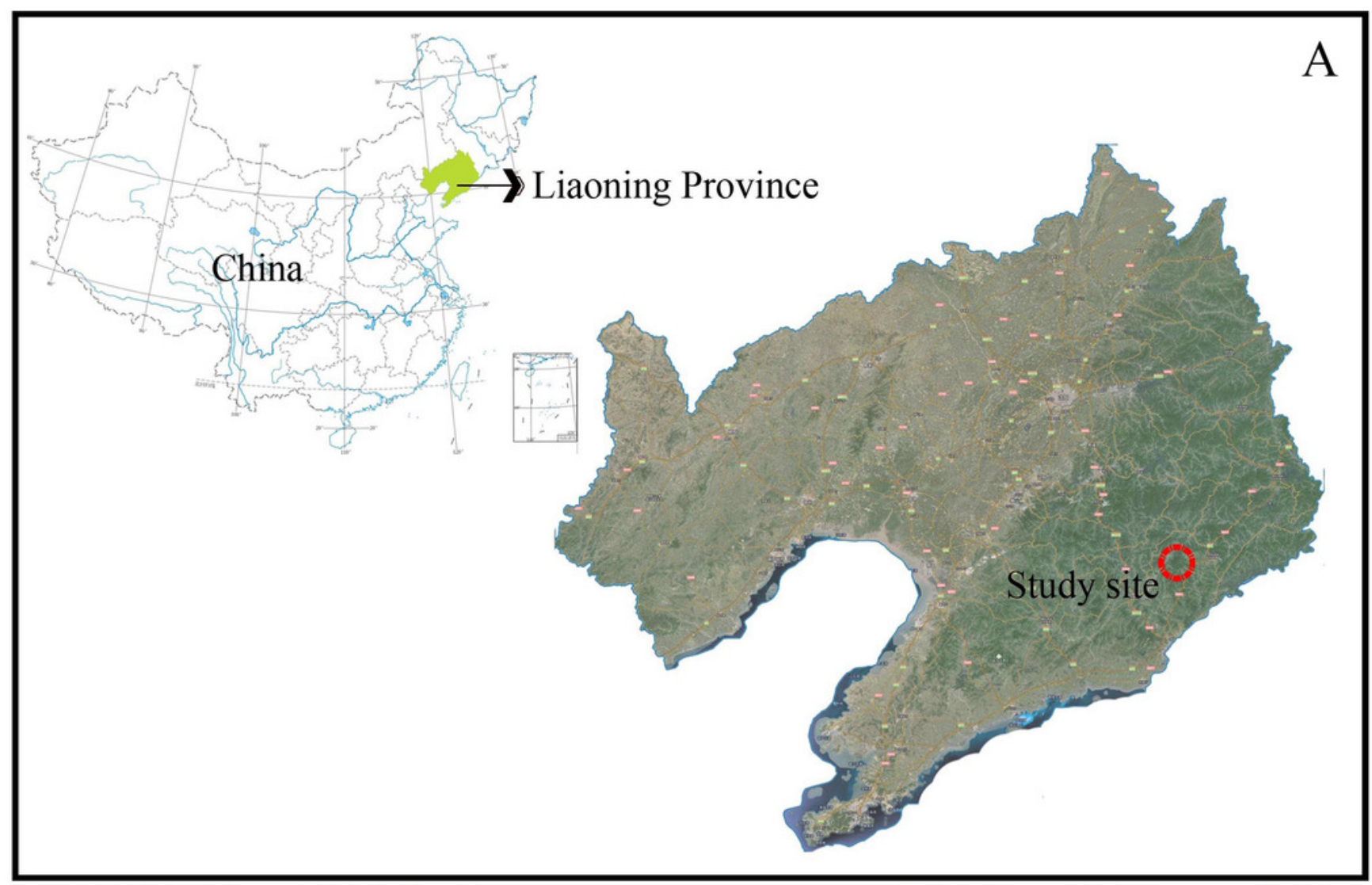

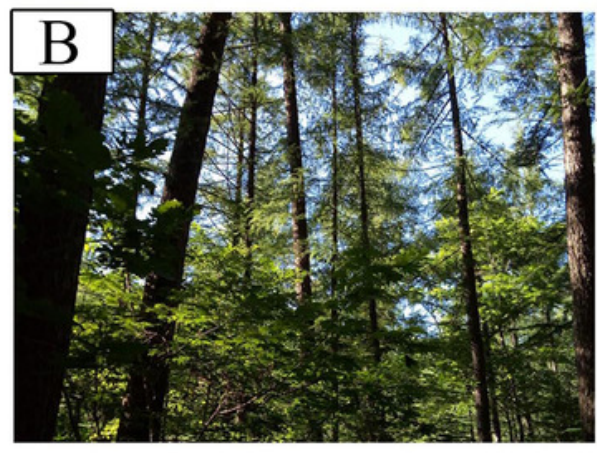

Larix gmelinii

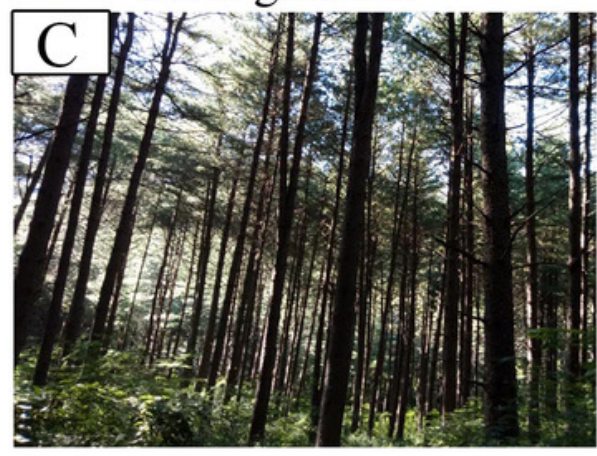

Pinus koraiensis
Different revegetation types

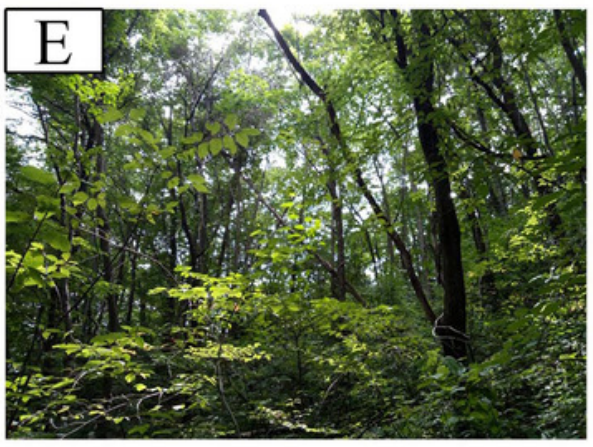

Juglans mandshurica

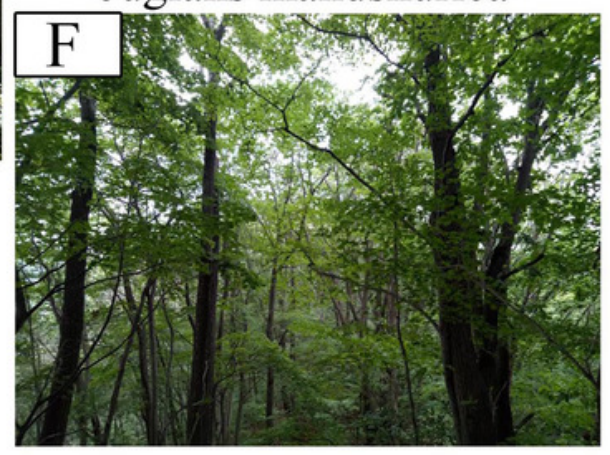

Quercus mongolica 
Figure 2

Results of principle component analysis-Biplot of the all investigated paramenters.

JM: Juglans mandshurica; QM: Quercus mongolica; CB: Conifer-broadleaf forest; LG: Larix gmelinii; PK: Pinus koraiensis. TN: Total N; TC: Total C; TP: Total P; AN: Available N; AP: Available $P$.

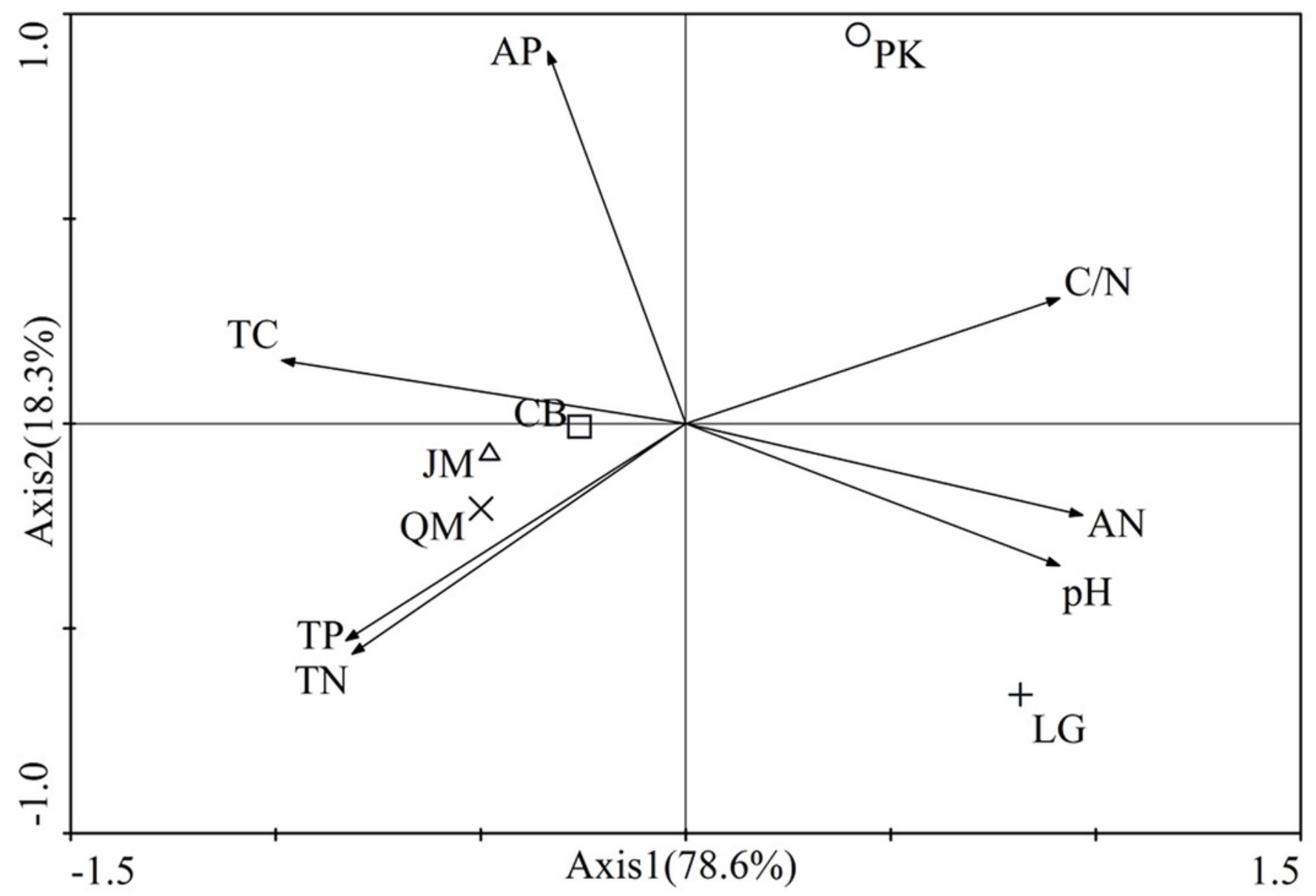


Figure 3

Rarefaction curves.

JM: Juglans mandshurica; QM: Quercus mongolica; CB: Conifer-broadleaf forest; LG: Larix gmelinii; PK: Pinus koraiensis.

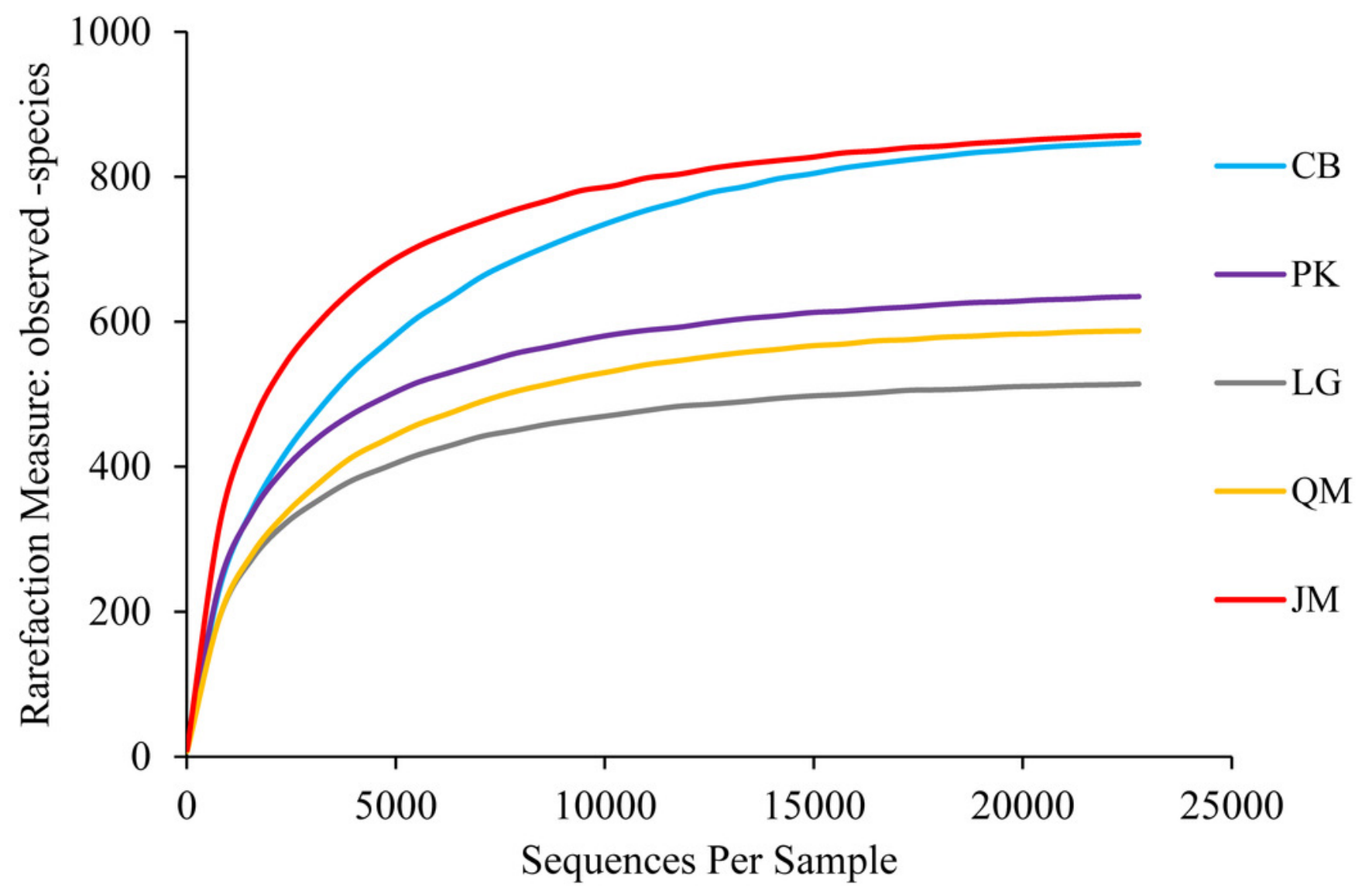


Figure 4

Relative abundance of fungus phyla present in 5 different revegetation types.

JM: Juglans mandshurica; QM: Quercus mongolica; CB: Conifer-broadleaf forest; LG: Larix gmelinii; PK: Pinus koraiensis.

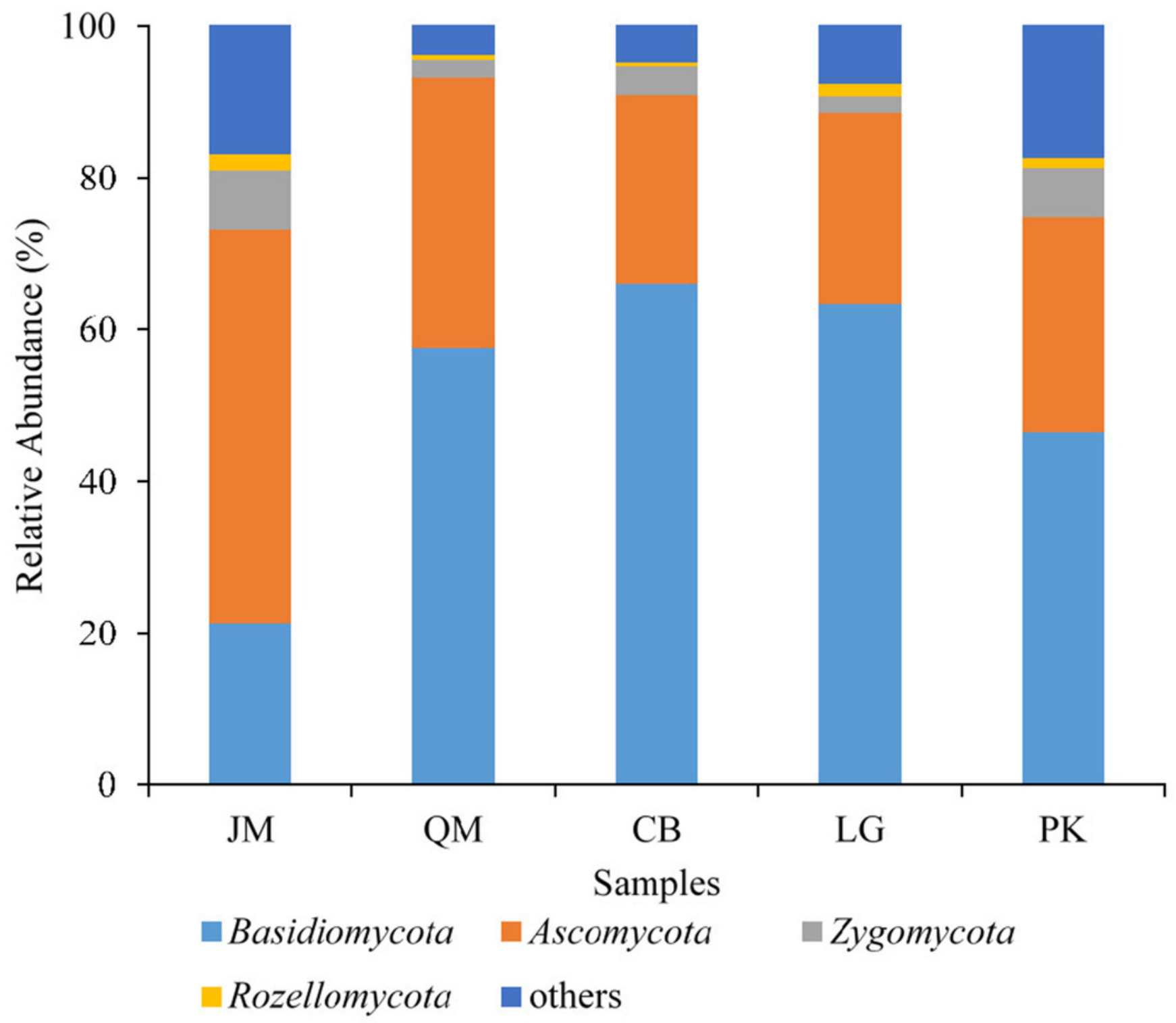




\section{Figure 5}

Venn diagrams of OUT richness.

JM: Juglans mandshurica; QM: Quercus mongolica; CB: Conifer-broadleaf forest; LG: Larix gmelinii; PK: Pinus koraiensis.

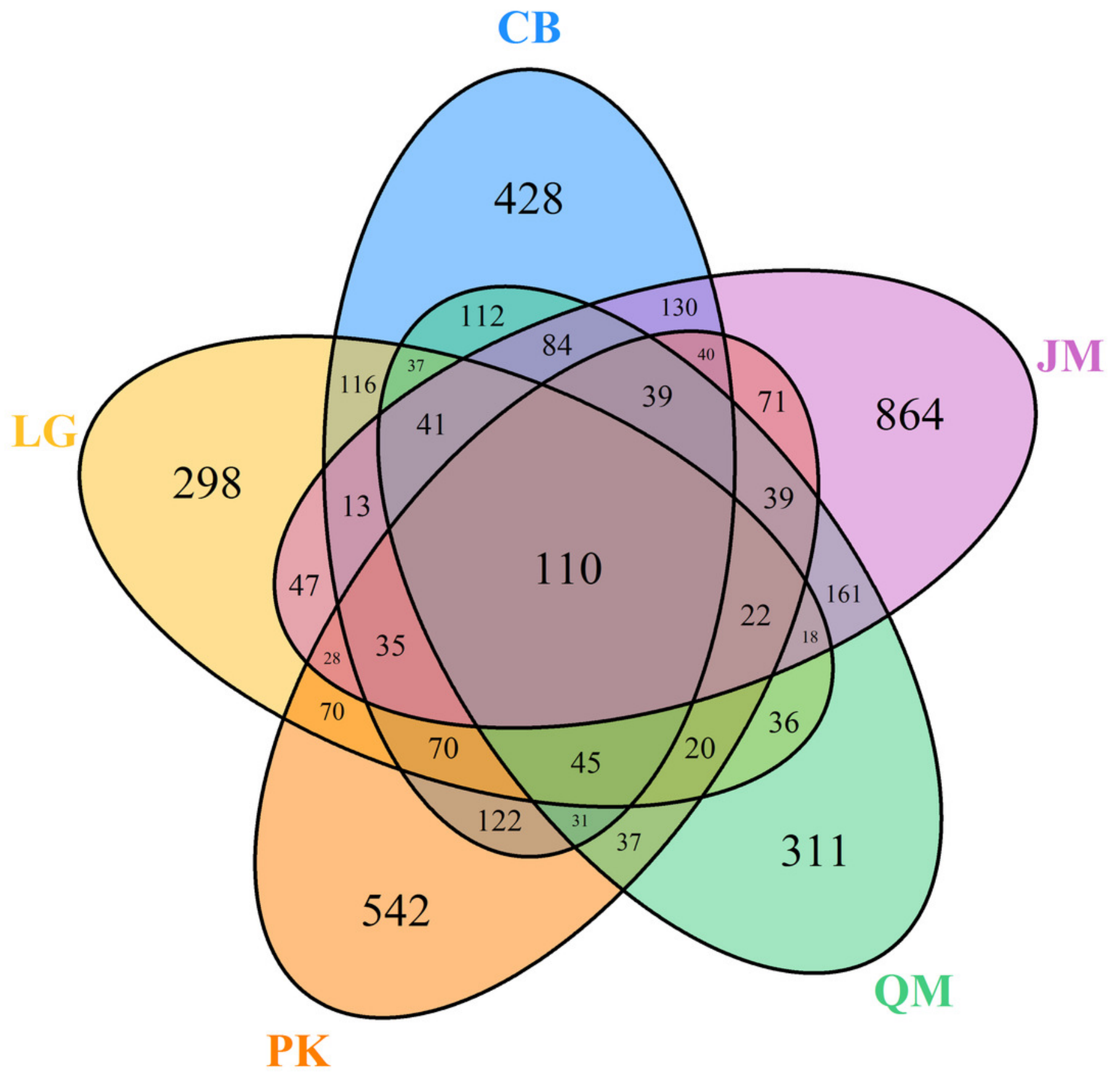




\section{Figure 6}

Heatmap and hierarchical cluster analysis based on the relative abundances of the top 50 genera identified in the bacterial communities of the soils.

JM: Juglans mandshurica; QM: Quercus mongolica; CB: Conifer-broadleaf forest; LG: Larix gmelinii; PK: Pinus koraiensis.

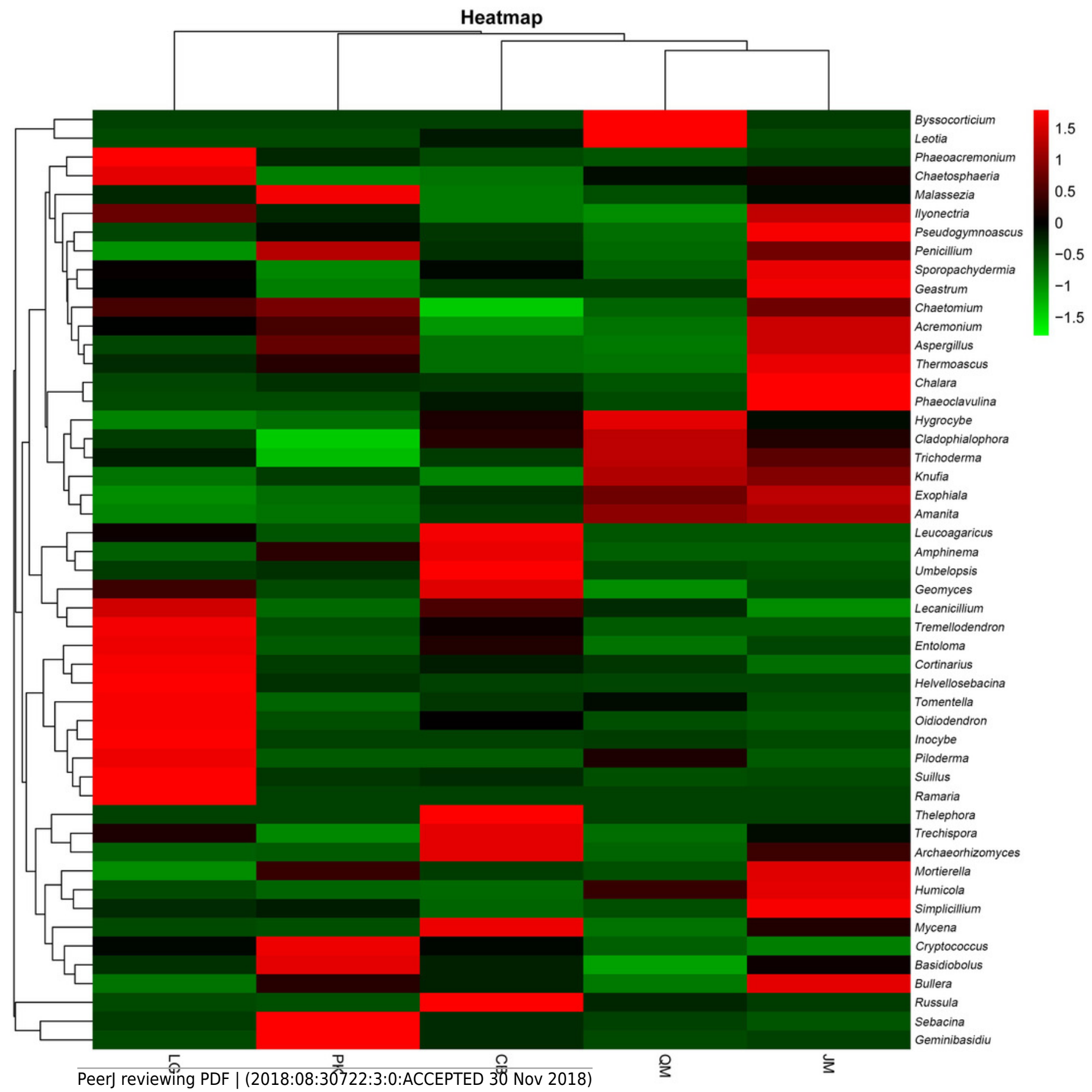


Figure 7

Weighted UniFrac NMDS analysis of the composition of fungal communities in the soil of forests with different dominant trees.

JM: Juglans mandshurica; QM: Quercus mongolica; CB: Conifer-broadleaf forest; LG: Larix gmelinii; PK: Pinus koraiensis.

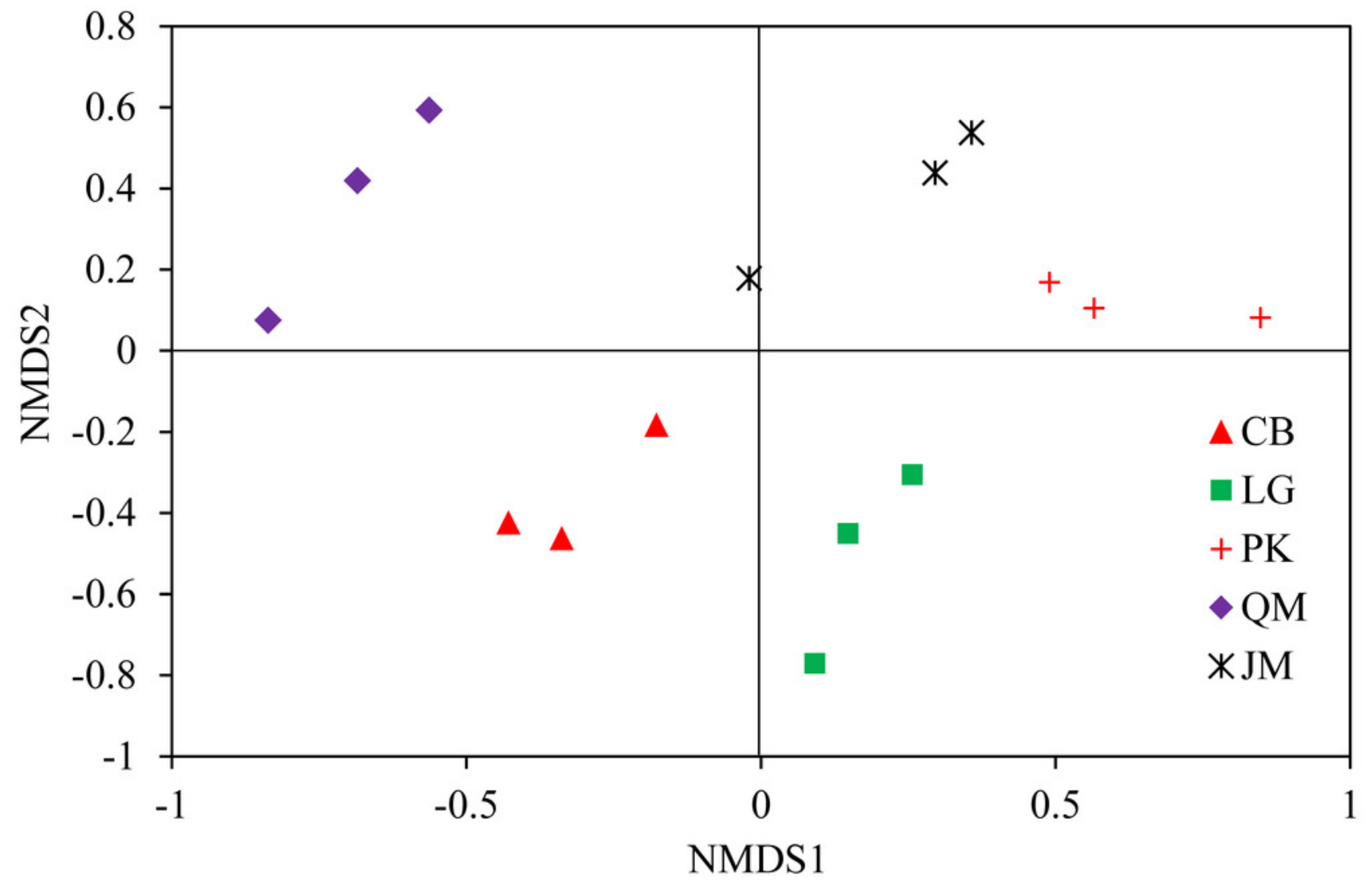




\section{Figure 8}

The cladogram of fungal communities among different sampling sites. In the cladogram, the circles radiating represent fungal taxon from phylum to genus from the inside.

JM: Juglans mandshurica; QM: Quercus mongolica; CB: Conifer-broadleaf forest; LG: Larix gmelinii; PK: Pinus koraiensis. 

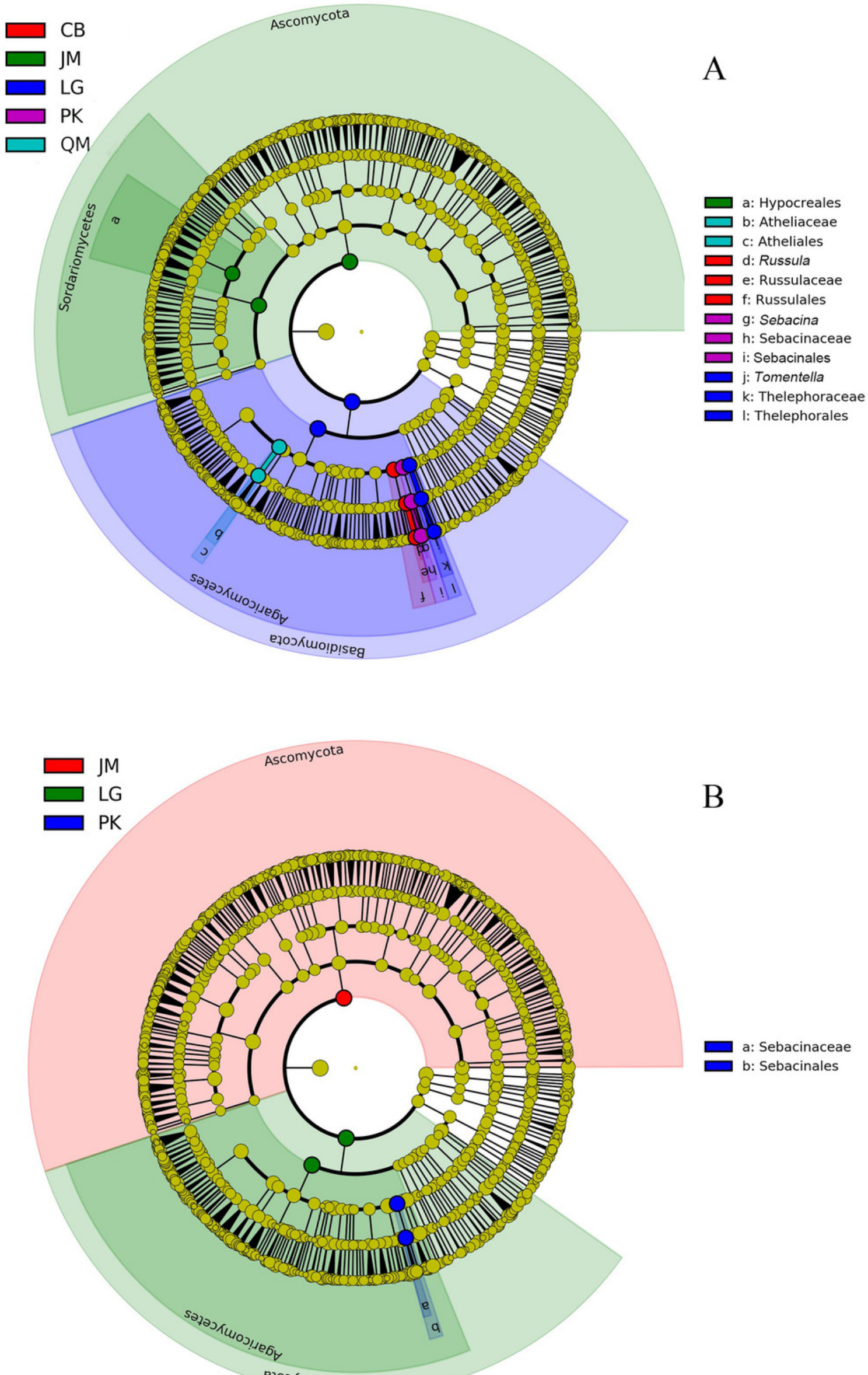
Figure 9

Canonical correspondence analysis (CCA) on soil dominant fungal phyla constrained by soil variables.

TN: Total N; TC: Total C; TP: Total P; AN: Available N; AP: Available P.

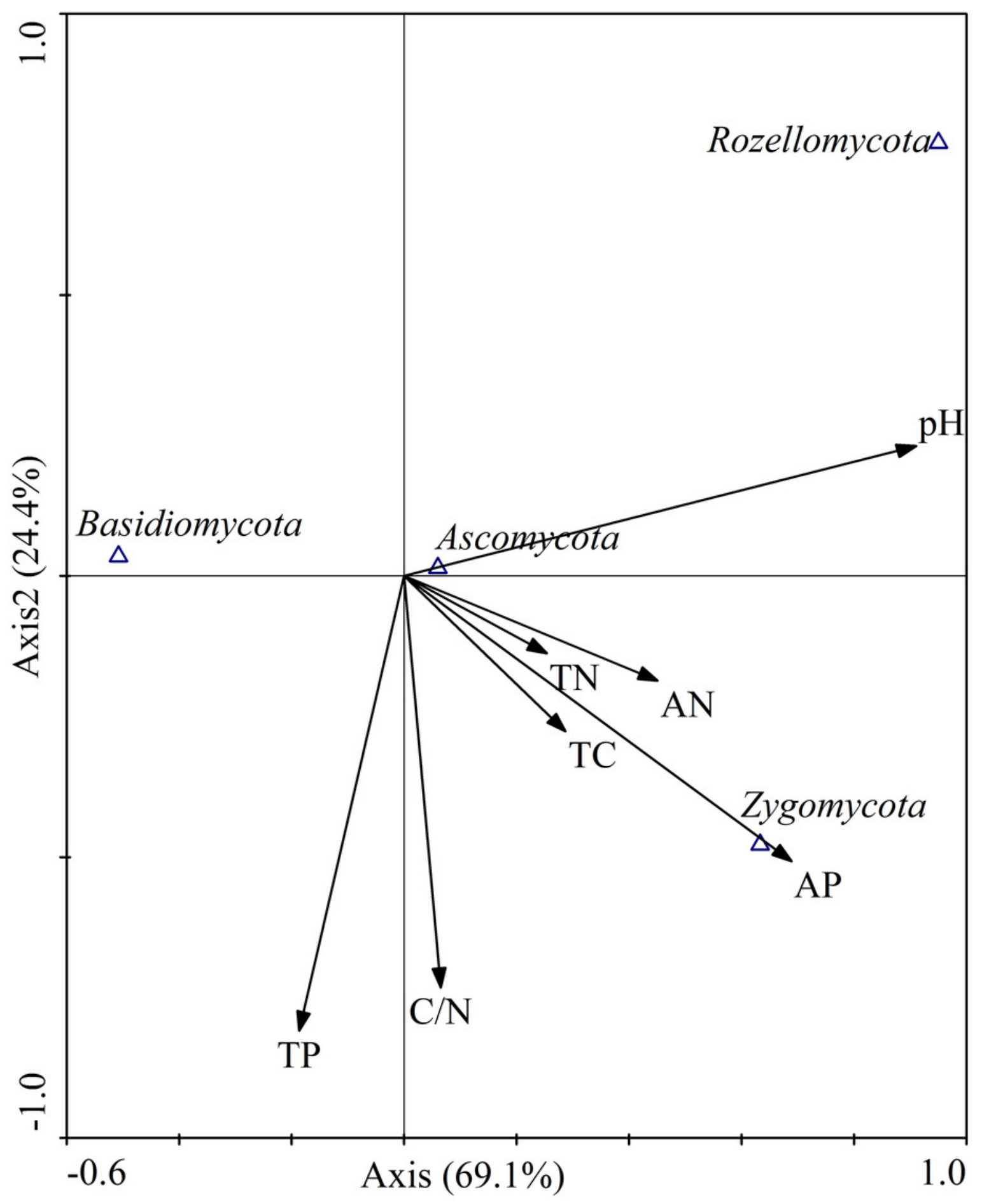




\section{Table $\mathbf{1}$ (on next page)}

Sites information of the Baishilazi Nature Reserve.

JM: Juglans mandshurica; QM: Quercus mongolica; CB: Conifer-broadleaf forest; LG: Larix gmelinii; PK: Pinus koraiensis. 
1 Table 1:

2 Sites information of the Baishilazi Nature Reserve.

\begin{tabular}{|l|l|l|l|}
\hline Vegetation types & Dominant species (m & $\begin{array}{l}\text { Elevation } \\
\text { above sea level) }\end{array}$ & Forest type \\
\hline JM & $\begin{array}{l}\text { Acanthopanax senticosus, Padus } \\
\text { racemose, Magnolia sieboldii, } \\
\text { Pimpinella brachycarpa, Puccinellia } \\
\text { tenuiflora }\end{array}$ & 901.8 & $\begin{array}{l}\text { Natural } \\
\text { secondary } \\
\text { forest }\end{array}$ \\
\hline Acermono, Cerasus tomentosa, Carpinus \\
cordata PB & $\begin{array}{l}\text { Betula ermanii, Pinus koraiensis, } \\
\text { Schisandra chinensis, Phryma } \\
\text { leptostachya L. subsp. asiatica }\end{array}$ & 826.5 & $\begin{array}{l}\text { Natural } \\
\text { secondary } \\
\text { forest }\end{array}$ \\
\hline LG & $\begin{array}{l}\text { Daemonorops margaritae } \\
\text { Daemonorops margaritae, Pteridium } \\
\text { aquilinum }\end{array}$ & 552.7 & $\begin{array}{l}\text { Natural } \\
\text { secondary } \\
\text { forest }\end{array}$ \\
\hline
\end{tabular}

3 Note:

4 JM: Juglans mandshurica; QM: Quercus mongolica; CB: Conifer-broadleaf forest; LG: Larix 5 gmelinii; PK: Pinus koraiensis.

6 


\section{Table 2 (on next page)}

Soil physical and chemical properties of different revegetation types.

Results from the ANOVAs are included ( $F$ test and $P$ value). Different letters in the same line $(a, b, c)$ indicate a significant difference at $P<0.05$. See table 1 for abbreviations. 
1 Table 2:

2 Soil physical and chemical properties of different revegetation types.

\begin{tabular}{|l|l|l|l|l|l|l|l|}
\hline $\begin{array}{l}\text { Chemical } \\
\text { features }\end{array}$ & JM & QM & CB & LG & PK & F test & $P$ value \\
\hline $\mathrm{pH}$ & $5.70 \mathrm{a}$ & $4.89 \mathrm{c}$ & $4.99 \mathrm{c}$ & $5.40 \mathrm{~b}$ & $5.48 \mathrm{~b}$ & 111.80 & $P<0.001$ \\
\hline $\begin{array}{l}\text { Total C } \\
\mathrm{kg})\end{array}$ & $100.53 \mathrm{a}$ & $84.62 \mathrm{~b}$ & $75.49 \mathrm{c}$ & $43.79 \mathrm{~d}$ & $41.70 \mathrm{~d}$ & 112.28 & $P<0.001$ \\
\hline $\begin{array}{l}\text { Total N }(\mathrm{g} / \\
\mathrm{kg})\end{array}$ & $7.80 \mathrm{a}$ & $7.38 \mathrm{a}$ & $5.47 \mathrm{~b}$ & $3.85 \mathrm{c}$ & $3.58 \mathrm{c}$ & 29.72 & $P<0.001$ \\
\hline $\mathrm{C} / \mathrm{N}$ & $12.89 \mathrm{ab}$ & $11.64 \mathrm{bc}$ & $13.81 \mathrm{a}$ & $11.36 \mathrm{c}$ & $11.65 \mathrm{bc}$ & 6.50 & $P=0.008$ \\
\hline $\begin{array}{l}\text { Total P } \\
\mathrm{kg})\end{array}$ & $0.93 \mathrm{~b}$ & $0.74 \mathrm{bc}$ & $1.46 \mathrm{a}$ & $0.62 \mathrm{c}$ & $0.77 \mathrm{bc}$ & 26.59 & $P<0.001$ \\
\hline $\begin{array}{l}\text { Available N } \\
(\mathrm{mg} / \mathrm{kg})\end{array}$ & $57.15 \mathrm{a}$ & $41.25 \mathrm{~b}$ & $43.60 \mathrm{~b}$ & $33.35 \mathrm{c}$ & $28.04 \mathrm{c}$ & 14.99 & $P<0.001$ \\
\hline $\begin{array}{l}\text { Available P } \\
(\mathrm{mg} / \mathrm{kg})\end{array}$ & $4.42 \mathrm{ab}$ & $2.39 \mathrm{ab}$ & $2.53 \mathrm{ab}$ & $1.21 \mathrm{~b}$ & $5.65 \mathrm{a}$ & 1.99 & $P=0.172$ \\
\hline
\end{tabular}

3 Note:

4 Results from the ANOVAs are included (F test and $P$ value). Different letters in the same line (a,

5 b, c) indicate a significant difference at $P<0.05$. See table 1 for abbreviations. 


\section{Table 3(on next page)}

Soil fungal diversity indexes of different revegetation types.

Different letters in the same line $(a, b, c)$ indicate a significant difference at $P<0.05$. JM:

Juglans mandshurica; QM: Quercus mongolica; CB: Conifer-broadleaf forest; LG: Larix gmelinii; PK: Pinus koraiensis. 
1 Table 3:

2 Soil fungal diversity indexes of different revegetation types.

\begin{tabular}{|l|l|l|l|l|l|l|}
\hline Types & $\begin{array}{l}\text { No. of } \\
\text { sequences }\end{array}$ & $\begin{array}{l}\text { OTUs } \\
\text { number } \\
\text { (phylum) }\end{array}$ & $\begin{array}{l}\text { Shannon } \\
\text { Index }\end{array}$ & ACE Index & Chao1 Index & $\begin{array}{l}\text { Simpson } \\
\text { Index }\end{array}$ \\
\hline JM & 40811 & 715 & $8.18 \pm 0.23 \mathrm{a}$ & $879.57 \pm 64.4767 \mathrm{a}$ & $879.08 \pm 64.48 \mathrm{a}$ & $0.99 \pm 0.00 \mathrm{a}$ \\
\hline QM & 33752 & 518 & $5.79 \pm 0.28 \mathrm{c}$ & $597.78 \pm 98.62 \mathrm{~b}$ & $598.00 \pm 98.89 \mathrm{~b}$ & $0.89 \pm 0.03 \mathrm{~b}$ \\
\hline $\mathrm{CB}$ & 37669 & 743 & $7.18 \pm 0.34 \mathrm{~b}$ & $870.95 \pm 192.83 \mathrm{a}$ & $866.17 \pm 184.59 \mathrm{a}$ & $0.98 \pm 0.01 \mathrm{a}$ \\
\hline LG & 37959 & 455 & $6.49 \pm 0.22 \mathrm{bc}$ & $522.15 \pm 100.95 \mathrm{~b}$ & $521.58 \pm 101.48 \mathrm{~b}$ & $0.97 \pm 0.01 \mathrm{a}$ \\
\hline PK & 63447 & 525 & $7.06 \pm 0.89 \mathrm{~b}$ & $650.67 \pm 108.58 \mathrm{~b}$ & $649.10 \pm 109.27 \mathrm{~b}$ & $0.97 \pm 0.02 \mathrm{a}$ \\
\hline
\end{tabular}

3 Note:

4 Different letters in the same line (a, b, c) indicate a significant difference at $P<0.05$. JM: Juglans

5 mandshurica; QM: Quercus mongolica; CB: Conifer-broadleaf forest; LG: Larix gmelinii; PK:

6 Pinus koraiensis.

7 


\section{Table 4 (on next page)}

Person's rank correlation coefficients between fungi diversity indices and measured soil characteristics.

${ }^{*}$ Correlation is significant at the 0.05 level (1-tailed). ${ }^{* *}$ Correlation is significant at the 0.01 level (2-tailed). 
1 Table 4:

2 Person's rank correlation coefficients between fungi diversity indices and measured soil 3 characteristics.

\begin{tabular}{|c|c|c|c|c|c|c|c|}
\hline & $\mathrm{pH}$ & Total C & Total N & $\mathrm{C} / \mathrm{N}$ & Available N & Total P & Available P \\
\hline Simpson & $\mathbf{0 . 6 8 0}^{* *}$ & -0.139 & -0.337 & 0.472 & -0.043 & 0.334 & 0.297 \\
\hline Chao1 & 0.089 & $\mathbf{0 . 5 7 3} *$ & 0.389 & $\mathbf{0 . 7 1 5} * *$ & 0.397 & $\mathbf{0 . 7 2 5} * *$ & 0.238 \\
\hline ACE & 0.085 & $\mathbf{0 . 5 6 7} *$ & 0.383 & $\mathbf{0 . 7 1 4} * *$ & 0.389 & $\mathbf{0 . 7 3 0} * *$ & 0.234 \\
\hline Shannon & $\mathbf{0 . 6 5 9} * *$ & 0.302 & 0.132 & $\mathbf{0 . 5 2 8} *$ & 0.312 & 0.361 & 0.508 \\
\hline
\end{tabular}

4 Note:

$5 *$ Correlation is significant at the 0.05 level (1-tailed). $* *$ Correlation is significant at the 0.01 level 6 (2-tailed).

7

8 


\section{Table 5 (on next page)}

Person's rank correlations between the relative abundances of dominant bacteria groups and available edaphic factors.

**correlation significant at 0.01 level (two-tailed); *correlation significant at 0.05 level (twotailed). 
1 Table 5:

2 Person's rank correlations between the relative abundances of dominant bacteria groups and

3 available edaphic factors.

\begin{tabular}{|c|c|c|c|c|c|c|c|}
\hline Fungal group & $\mathrm{pH}$ & Total C & Total N & $\mathrm{C} / \mathrm{N}$ & Available N & Total P & Available P \\
\hline Phylun & -- & - & - & - & - & - & - \\
\hline Basidiomycota & $-0.680^{* *}$ & -0.455 & -0.466 & -0.010 & -0.506 & 0.107 & $-0.611^{* *}$ \\
\hline Ascomycota & 0.416 & $0.608^{*}$ & $0.655^{* *}$ & -0.004 & $0.693^{* *}$ & -0.058 & 0.462 \\
\hline Zygomycota & $0.530^{*}$ & 0.274 & 0.179 & 0.284 & 0.245 & 0.146 & $0.665^{* *}$ \\
\hline Rozellomycota & $0.716^{* *}$ & -0.016 & 0.036 & -0.278 & 0.052 & -0.460 & 0.002 \\
\hline Genus & - & - & - & - & - & - & - \\
\hline Sebacina & 0.192 & $-0.563^{*}$ & $-0.533^{*}$ & -0.282 & $-0.604^{*}$ & -0.132 & 0.171 \\
\hline Russula & -0.491 & 0.170 & 0.025 & $0.637^{*}$ & 0.171 & $0.751^{* *}$ & -0.121 \\
\hline Tomentella & 0.009 & -0.407 & -0.339 & -0.371 & -0.247 & -0.360 & -0.473 \\
\hline Mortierella & $0.524^{*}$ & 0.456 & 0.383 & 0.264 & 0.447 & 0.123 & $0.623^{*}$ \\
\hline Trechispora & -0.182 & 0.096 & -0.039 & 0.490 & 0.071 & $0.593^{*}$ & -0.415 \\
\hline Piloderma & -0.066 & -0.378 & -0.278 & -0.452 & -0.316 & $-0.534^{*}$ & -0.482 \\
\hline Humicola & 0.302 & $0.745^{* *}$ & $0.735^{* *}$ & 0.146 & $0.705^{* *}$ & -0.098 & 0.152 \\
\hline Suillus & 0.118 & -0.438 & -0.402 & -0.287 & -0.263 & -0.236 & -0.266 \\
\hline Geminibasidium & 0.252 & $-0.530 *$ & $-0.516^{*}$ & -0.226 & $-0.569^{*}$ & -0.105 & 0.271 \\
\hline Ramaria & 0.116 & -0.420 & -0.378 & -0.303 & -0.353 & -0.402 & -0.368 \\
\hline Archaeorhizomyces & -0.111 & 0.300 & 0.132 & $0.672^{* * *}$ & 0.334 & $0.591^{*}$ & -0.057 \\
\hline Cryptococcus & 0.114 & $-0.655^{* *}$ & $-0.655^{* *}$ & -0.212 & $-0.698^{* *}$ & -0.069 & -0.031 \\
\hline Simplicillium & $0.540^{*}$ & 0.415 & 0.380 & 0.110 & 0.387 & -0.009 & 0.509 \\
\hline Oidiodendron & 0.024 & -0.417 & -0.398 & -0.211 & -0.261 & -0.098 & -0.338 \\
\hline Inocybe & 0.144 & $-0.518^{*}$ & -0.459 & -0.397 & -0.340 & -0.383 & -0.380 \\
\hline Basidiobolus & 0.431 & -0.378 & -0.434 & 0.023 & -0.406 & -0.143 & $0.578^{*}$ \\
\hline Bullera & $0.596^{*}$ & 0.340 & 0.273 & 0.231 & 0.313 & 0.091 & 0.357 \\
\hline
\end{tabular}

4 Note:

$5 * *$ correlation significant at 0.01 level (two-tailed); *correlation significant at 0.05 level (two6 tailed). 